\title{
HEAVY METALS CONTENT IN CANNED TUNA FISH MARKETED IN ASSIUT CITY, EGYPT AND ITS RELATED HUMAN HEALTH RISK ASSESSMENT
}

\author{
AHMED A. SHARKAWY ${ }^{1}$; ABEERA M. EL-SAYED ${ }^{2}$ AND MOHAMMED A.M. ALI ${ }^{1}$ \\ ${ }^{1}$ Forensic Medicine and Toxic. Dept., Fac. of Vet. Medicine, Assiut Uni., Assiut, Egypt. \\ ${ }^{2}$ Fellow - Sohag University Hospital, Sohag University, Sohag, Egypt.
}

\author{
Received: 19 February 2020; Accepted: 9 March 2020
}

\begin{abstract}
Some heavy metals are harmful and dangerous and cause many risks for food and public health. Also accumulated in fish such as tuna fish as a result of contaminated water or during transport, processing or canning. The present study was conducted to measure the concentration of some heavy metals $(\mathrm{Pb}, \mathrm{Cd}, \mathrm{Al}$, $\mathrm{Hg}, \mathrm{Ni}, \mathrm{Co}$ and $\mathrm{Cr}$ ) in canned tuna of five brands. Materials and Methods: Forty canned tuna samples from five brands were examined to determine their metal concentration. The samples were collected from supermarkets found in Assiut city (Egypt) from June 2017 to November 2017. The metals were determined using Atomic Absorption Spectrometer Perkin Elymer (Analyst 400) for $\mathrm{Pb}, \mathrm{Cd}, \mathrm{Co}, \mathrm{Ni}$ and $\mathrm{Cr}$ while $\mathrm{Hg}$ was estimated by using ICP (iCAP 6200) and Al was determined using Atomic Absorption Spectrometer (ZEEnit700P). Results: The results revealed that the levels (ppm wet weight) of metals were as following in the examined five brands: (1) Lead: 1.984 \pm 0.156 (1.378-2.256), 2.581 \pm 0.401 (1.305-3.778), $1.804 \pm 0.244$ (1.190-2.425), $2.030 \pm 0.424$ (1.144-3.459), 1.752 $\pm 0.250(1.200-2.616)$ while in total samples was 2.030 \pm 0.141 (1.144-3.778). (2) Cadmium: 0.617 \pm 0.04 (0.467-0.696), 0.681 \pm 0.043 (0.536-0.778), $0.615 \pm 0.041(0.516-0.720), 0.651 \pm 0.053(0.519-0.747), 0.701 \pm 0.038(0.561-0.792)$ while in total samples was $0.653 \pm 0.019$ (0.467-0.792). (3) Aluminum: $3.545 \pm 0.017$ (3.510-3.605), 3.707 \pm 0.058 (3.500-3.858), $3.525 \pm 0.125$ (3.152-3.938), 3.676 \pm 0.044 (3.524-3.799), 3.635 \pm 0.159 (3.074-4.049), while in total samples was 3.617 \pm 0.042 (3.074-4.049). (4) Mercury: $6.640 \pm 0.075$ (6.385-6.807), 5.105 \pm 0.025 (5.039-5.171), $6.823 \pm 0.077$ (6.611-7.035), 2.948 \pm 0.120 (2.615-3.281), 1.745 \pm 0.156 (1.301-2.189), while in total samples was 4.652 \pm 0.413 (1.301-7.035). (5) Nickel: $2.035 \pm 0.148$ (1.444-2.202), $1.948 \pm 0.155$ (1.375-2.302), $1.924 \pm 0.159(1.531-2.250), 1.906 \pm 0.215(1.384-2.352), 1.957 \pm 0.127$ (1.548-2.283), while in total samples was $1.954 \pm 0.067$ (1.384-2.352). (6) Cobalt: $1.322 \pm 0.149$ (0.765-1.656), $1.757 \pm 0.082$ (1.515-1.957), $2.089 \pm 0.165(1.607-2.525), 2.511 \pm 0.123(2.160-2.785), 2.719 \pm 0.1102 .381-3.072)$, while in total samples was 2.080 \pm 0.16 (0.765-3.072). (7) Chromium: 0.246 \pm 0.100 (0.000-0.573), 0.039 \pm 0.03 (0.000-0.156), ND, $\mathrm{ND}, 0.030 \pm 0.023(0.000-0.120)$, while in total samples was $0.063 \pm 0.027$ (ND-0.573). In this study, the Target Health Quotient (THQ) in the total examined tuna samples was $0.219-0.323$ (0.254) for Pb, 0.3080.351 (0.327) for $\mathrm{Cd}, 0.00176-0.00185$ (0.00181) for $\mathrm{Al}, 2.913-11.380$ (7.757) for $\mathrm{Hg}, 0.047-0.051$ (0.049) for Ni, 0.033-0.049 (0.052) for Co and 0.00001-0.000082 (0.000035) for $\mathrm{Cr}$ while the Hazard Health Index (HI) for all metals was 11.709for brand 1, 9.268 for brand 2, 12.015 for brand 3, 5.604 for brand 4, 3.601 for brand 5 , all of these are exceeding 1 .

Conclusion: The calculated hazard index (HI) in this study in all examined canned tuna in all brands exceeds 1 . The data indicate that the examined canned tuna were polluted with $\mathrm{Pb}, \mathrm{Cd}, \mathrm{Al}, \mathrm{Hg}$ and $\mathrm{Ni}$. Hazard indices for the estimated metals in these canned tuna imply that excessive and continuous intake of these tuna could result in chronic adverse health effects on the consumers. However, consumption of large quantities of these canned tuna increases human exposure to the risk especially of $\mathrm{Hg}$ toxicity. Recommendation: It recommended that more studies for assessment for quality control should be done to help safeguard the health consumers.
\end{abstract}

Key words: Canned tuna, pollution, heavy metals, health risk assessment, Hazard Index.

Corresponding author: AHMED A. SHARKAWY

E-mail address: ahmedsharkawy61@yahoo.com

Present address: Forensic Medicine and Toxic. Dept., Fac. of Vet. Medicine, Assiut Uni., Assiut, Egypt 


\section{INTRODUCTION}

Kazi et al. (2009) and Ozden (2010) mentioned that environmental pollution with different pollutants either industrial or agricultural wastes represents a major problem and great challenges all over the world. Today, the rapid progress of many industrial processes resulted in pollution with heavy metals that induce many adverse effects to the human through consumption of food (Yilmaz, 2009). The high levels of metals in the environment can be accumulated in the animal and human tissues because these metals are poorly degraded either in the environment or inside the tissues (Ciesielski et al., 2010).

Fish represent a good source of protein which contains essential amino acids, many elements (calcium, fluorine, iodine and phosphorus) and fats. This fat is a source of energy and rich in fat soluble vitamins and unsaturated fatty acids which have many benefits such as hypocholesterolic effect (anti-atheriosclerosis) (Ismail, 2005). Sirot et al. (2010) reported that fish and other sea foods are important food source for human as they considered health and balanced meals.

Fish are good bioindicator for detection of contamination by heavy metals in the aquatic system. Fish can easily absorb the pollutants especially metals from the polluted water and feed and bioaccumulate them in their tissues (Burger et al., 2002). Heavy metals in any chemical form in water can be taken by fish and transported to the human via food chain resulting in much toxicity (Rauf et al., 2009 and Tuzen, 2009).

Tuna is characterized with high metabolic rate, high food intake and high accumulation capacity for metallic pollutants. Tuna is one of the most consumed fish all over the world (Burger and Gochfeld, 2004 and Kojadinovic et al., 2007).

Aluminum ( $\mathrm{Al})$ is found in the atmospheric air of most industrialized overcrowded cities (Casarini et al., 2001) and used in treatment of water (Silva et al., 2007 and Camargo et al., 2009). Al induced much toxicity to the marine animals (Correia et al., 2010). The essentiality of the human body to $\mathrm{Al}$ is not found. Exposure of human to $\mathrm{Al}$ can cause many diseases like Parkinson's disease, Alzheimer's disease and encephalopathy/ dialysis dementia (Narin et al., 2004).

Cadmium $(\mathrm{Cd})$ is a cumulative contaminant and induces many toxic effects. $\mathrm{Cd}$ and lead $(\mathrm{Pb})$ have been classified by International Agency for Research on Cancer (IARC) as human carcinogens (IARC, 1993). Exposure to high levels of $\mathrm{Cd}$ induces nephrotoxicity, bone effects, neurotoxicity, carcinogenicity, teratogenicity, respiratory, endocrinal and reproductive effects (EFSA, 2009, Ciobanu et al., 2012; Engström et al., 2012, Satarug, 2012 and Sawada et al., 2012).

Lead is an environmental pollutant and results in many adverse health hazards and toxicities. Children are highly susceptible to $\mathrm{Pb}$ than adults due to high gastrointestinal uptake, tissue accumulation and high blood brain barrier permeability (Jarup, 2003). Pb causes central nervous system disorders, anemia, learning difficulties, behavioral disturbances, impairment of intellectual capacity, gastrointestinal and hemobiotic disturbances, effects on the renal and musculoskeletal systems as well as genetic effects (Kakkar and Jaffery, 2005; Jomova and Valko, 2011 and Ciobanu et al., 2012).

Mercury $(\mathrm{Hg})$ is present in air, soil and water. Large amounts of $\mathrm{Hg}$ are distributed in the environment as a result of anthropogenic and natural activities (WHO, 2008). Mercury accumulates in the fleshy tissue of fish. When consumed induces growth changes in the brain of children and neurological disorders in adults (Commission of the European Communities, 2001; Ikem and Egiebor, 2005).

Nickel (Ni) acts as activator of some enzymatic systems and due to its accumulation in the lungs result in toxicity at high levels. Food can be contaminated with $\mathrm{Ni}$ as well as during food processing (cooking and canning in vessels containing Ni. According to the US EPA, the oral reference dose of $\mathrm{Ni}$ is $20 \mu \mathrm{g} / \mathrm{kg} / \mathrm{day}$ and the provisional maximum tolerable daily intake is 1.2 mg Ni /person/day (Ashraf et al., 2006).

Cobalt (Co) is an essential element and an integral part of vitamin $\mathrm{B}_{12}$. Co enhancing the thyroid functions. High levels of Co induce adverse effects in the heart (congestive heart failure), polycythemia, lung and skin (ATSDR, 2004), while Co deficiency can result in anemia (Jan et al., 2010).

Chromium (Cr) plays an important role as an enzyme cofactor. In spite of its essentiality, it accumulates in the liver and spleen resulting in toxicity (Wagner and Boman, 2003). $\mathrm{Cr}$ as an essential nutrient potentiates the action of insulin that influences the metabolism of protein, lipids and carbohydrates. $\mathrm{Cr}(\mathrm{VI})$ is carcinogenic (Tuzen, 2007).

The discharge of effluents into the lakes due to rapid urbanization and industrialization is a big concern worldwide now days (Akan et al., 2012). A number of toxic pollutants are added to the 
aquatic environment. Due to their action and persistence in biological amplification, heavy metals are particularly more dangerous (Erdogrul and Erbilir 2007, Honggang et al., 2010, Babatunde et al., 2012). Atmospheric deposition, mining wastes and erosion of the geological matrix are the main sources through which metals can enter the aquatic environment. Even at quite low concentrations most of the toxic metals are harmful to the living organisms but some are biologically essential and natural constituents of aquatic ecosystems, they can cause hazards at very high concentrations (Abida et al., 2008, Bahnasawy et al., 2011).

From the previously mentioned, the aim of this study is (1) to estimate the levels of different heavy metals such as $\mathrm{Al}, \mathrm{Cd}, \mathrm{Pb}, \mathrm{Hg}, \mathrm{Ni}$ and $\mathrm{Cr}$ in different brands of canned tuna, (2) to estimate the intake (daily and weekly) of these metals due to consumption of these canned tuna and (3) to calculate the health risk hazard and comparing them to the professional tolerable weekly intake (PTWI) and professional tolerable daily intake PTDI as well as the total target hazard quotient (TTHQ) for these metals as recommended by various agencies.

\section{MATERIALS AND METHODS}

(1) Chemicals: All the chemicals used were of analytical grade. To avoid contamination with metals the glassware and the containers used were cleaned by soaking in a $10 \%$ nitric acid solution for up to 24 hours and then rinsed three times with bi-distilled water before use. Standard stock solutions of $\mathrm{Pb}, \mathrm{Cd}, \mathrm{Al}, \mathrm{Hg}, \mathrm{Ni}, \mathrm{Co}$ and $\mathrm{Cr}$ were prepared from Titrasol $(1000 \mathrm{mg} / \mathrm{L})$ and were diluted to the related metal solution.

\section{(2) Samples:}

A-Samples collection: Forty canned tuna samples from five brands were examined to determine their metal concentration. The samples were collected from supermarkets found in Assiut city (Egypt) from June 2017 to November 2017. The examined canned tuna fish are:

Brand 1: Skipjacks (Katsuwonus Pelamis), Brand 2: Skipjacks (Katsuwonus Pelamis), Brand 3: Bonito fish (Sarda sarda: Scomber palmitus, Scomber ponticus, Scomber mediterraneus and Thynnus brachypterus). Brand 4: Skipjacks (Katsuwonus Pelamis), Brand 5: Common Dolfin fish (Coryphaena hippurus)

B- Samples preparation: After opening each can, oil was drained off and the meat was homogenized thoroughly in a food blender with stainless steel cutters. About one gram from each sample was weighed into $25 \mathrm{ml}$ Erlenmeyer flasks, $5 \mathrm{ml}$ pure nitric acid (65\%; from Merck, Germany) was added to each sample, and the samples were left overnight. Thereafter, $2.5 \mathrm{ml}$ perchloric acid (72\%; from Merck, Germany) was added to each sample. The samples were then placed on a hot plate and allowed to digest until a transparent and clear solution was obtained. Samples were allowed to cool and then diluted to $50 \mathrm{ml}$ with double distilled water. The concentrations of metals in the samples are presented as $\mathrm{mg} / \mathrm{kg}$ wet weight. Samples were digested according to methods described by $\mathrm{Du}$ Preez and Steyn (1992).

(3) Metals analysis: Heavy metals in this study were measured using the following instruments: (1) $\mathrm{Pb}, \mathrm{Cd}, \mathrm{Co}, \mathrm{Ni}$ and $\mathrm{Cr}$ were determined using Atomic Absorption Spectrometer Perkin Elymer (Analyst 400), Atomic Absorption Unit, Fac. Of Science, Sohag University. (2) Al was determined using Atomic Absorption Spectrometer (ZEEnit700P) with graphite tube, Central lab., Fac. Of Veterinary Medicine, Assiut University. (3) $\mathrm{Hg}$ was determined using ICP (Inductively Coupled Plasma Emission Spectrometer, iCAP 6200), Central lab for Chemical Analysis, Fac. Of Agriculture, Assiut University.

(4) Statistical analyses: Data were analyzed via one-way analysis of variance (ANOVA). All statistical analyses of data were performed by SPSS 16.0 (SPSS Inc., Chicago, IL, USA) software (SPSS, 2001).

\section{(5) Health Risk Assessment:}

[1] The estimated daily and weekly intakes: The estimated daily intakes (EDI) or weekly intakes (EWI) and EWI/provisional tolerable weekly intake (PTWI) ratio for estimated heavy metals in canned tuna. The EDI or EWI for investigated heavy metals in canned tuna samples were estimated according to the following equation:

$$
\begin{gathered}
\text { Metal concentration in sample }(\mathrm{ug} / \mathrm{kg}) \times \text { Food } \\
\text { intake (fish } \mathrm{kg} / \text { day) }
\end{gathered}
$$

EDI $=$

$$
\text { Body weight (70 kg for adult person) }
$$

Where $\mathrm{C}$ metal is the average concentration of $\mathrm{Pb}$ and $\mathrm{Cd}$ in fish; $\mathrm{W}$ represents the daily average consumption of marine fish and bw is body weight, set to $70 \mathrm{~kg}$. PTWI standard levels were provided by the European Food Safety Authority (EFSA, 2009; Song et al. 2009). EDI is measured in ( $\mathrm{mg} / \mathrm{kg}$ body weight/day)

[2] Target Hazard Quotient (THQ): Potential non-carcinogenic effects were evaluated by calculating a target hazard quotient (THQ). For a single compound, the target hazard quotient (THQ) is the ratio of the EDI to a reference dose: 
THQ (mg/kg) = $\frac{\text { EDI (mg/kg) }}{\text { RfD (mg/kg) }}$

Where: EDI is estimated daily intake ( $\mathrm{mg} / \mathrm{kg} / \mathrm{day})$; RfD is reference dose.

The Hazard Health Index (HI) of heavy metals for fish is the sum of the following composition according to USEPA (1991):
$\mathbf{H I}=\mathrm{THQ}(\mathrm{Pb})+\mathrm{THQ}(\mathrm{Cd})+\mathrm{THQ}(\mathrm{Al})+\mathrm{THQ}$

$(\mathrm{Hg})+$ THQ $(\mathrm{Ni})+$ THQ $(\mathrm{Co})+$ THQ $(\mathrm{Cr})$.

\section{RESULTS}

The results of this study were summarized in the following tables (1-7) and figures. The results here were in mean $\pm \mathrm{SE}$.

Table 1: Heavy metals concentrations (ppm) in the different brands of examined canned tuna samples.

\begin{tabular}{|c|c|c|c|c|c|c|c|c|}
\hline \multicolumn{2}{|c|}{ Tuna brands } & $\mathbf{P b}$ & Cd & Al & $\mathrm{Hg}$ & $\mathbf{N i}$ & Co & $\mathrm{Cr}$ \\
\hline \multirow{2}{*}{ Brand 1} & $\begin{array}{l}\text { mean } \\
\pm \mathrm{SE}\end{array}$ & $\begin{array}{c}1.984 \pm \\
0.156\end{array}$ & $\begin{array}{c}0.617 \pm \\
0.040\end{array}$ & $\begin{array}{c}3.545 \pm \\
0.017\end{array}$ & $\begin{array}{c}6.640 \pm \\
0.075\end{array}$ & $\begin{array}{c}2.035 \pm \\
0.148\end{array}$ & $\begin{array}{c}1.322 \pm \\
0.149\end{array}$ & $\begin{array}{c}0.246 \pm \\
0.100\end{array}$ \\
\hline & Range & $\begin{array}{l}1.378- \\
2.256 \\
\end{array}$ & $\begin{array}{c}0.467- \\
0.696 \\
\end{array}$ & $\begin{array}{c}3.510- \\
3.605 \\
\end{array}$ & $\begin{array}{c}6.385- \\
6.807 \\
\end{array}$ & $\begin{array}{l}1.444- \\
2.202 \\
\end{array}$ & $\begin{array}{c}0.765- \\
1.656 \\
\end{array}$ & $\begin{array}{c}0.000- \\
0.573 \\
\end{array}$ \\
\hline \multirow{2}{*}{ Brand 2} & $\begin{array}{l}\text { mean } \\
\pm \mathrm{SE}\end{array}$ & $\begin{array}{c}2.581 \pm \\
0.401\end{array}$ & $\begin{array}{c}0.681 \pm \\
0.043\end{array}$ & $\begin{array}{c}3.707 \pm \\
0.058\end{array}$ & $\begin{array}{c}5.105 \pm \\
0.025\end{array}$ & $\begin{array}{c}1.948 \pm \\
0.155\end{array}$ & $\begin{array}{c}1.757 \pm \\
0.082\end{array}$ & $\begin{array}{c}0.039 \pm \\
0.030\end{array}$ \\
\hline & Range & $\begin{array}{l}1.305- \\
3.778 \\
\end{array}$ & $\begin{array}{c}0.536- \\
0.778 \\
\end{array}$ & $\begin{array}{c}3.500- \\
3.858 \\
\end{array}$ & $\begin{array}{l}5.039- \\
5.171 \\
\end{array}$ & $\begin{array}{l}1.375- \\
2.302\end{array}$ & $\begin{array}{c}1.515- \\
1.957 \\
\end{array}$ & $\begin{array}{c}0.000- \\
0.156\end{array}$ \\
\hline \multirow{2}{*}{ Brand 3} & $\begin{array}{l}\text { mean } \\
\pm \mathrm{SE}\end{array}$ & $\begin{array}{c}1.804 \pm \\
0.244 \\
\end{array}$ & $\begin{array}{c}0.615 \pm \\
0.041 \\
\end{array}$ & $\begin{array}{c}3.525 \pm \\
0.125 \\
\end{array}$ & $\begin{array}{c}6.823 \pm \\
0.077 \\
\end{array}$ & $\begin{array}{c}1.924 \pm \\
0.159 \\
\end{array}$ & $\begin{array}{c}2.089 \pm \\
0.165 \\
\end{array}$ & ND \\
\hline & Range & $\begin{array}{l}1.190- \\
2.425 \\
\end{array}$ & $\begin{array}{c}0.516- \\
0.720 \\
\end{array}$ & $\begin{array}{c}3.152- \\
3.938 \\
\end{array}$ & $\begin{array}{c}6.611- \\
7.035 \\
\end{array}$ & $\begin{array}{l}1.531- \\
2.250\end{array}$ & $\begin{array}{l}1.607- \\
2.525 \\
\end{array}$ & ND \\
\hline \multirow{2}{*}{ Brand 4} & $\begin{array}{l}\text { mean } \\
\pm \mathrm{SE}\end{array}$ & $\begin{array}{c}2.030 \pm \\
0.424 \\
\end{array}$ & $\begin{array}{c}0.651 \pm \\
0.053 \\
\end{array}$ & $\begin{array}{c}3.676 \pm \\
0.044 \\
\end{array}$ & $\begin{array}{c}2.948 \pm \\
0.120 \\
\end{array}$ & $\begin{array}{c}1.906 \pm \\
0.215 \\
\end{array}$ & $\begin{array}{c}2.511 \pm \\
0.123 \\
\end{array}$ & ND \\
\hline & Range & $\begin{array}{c}1.144- \\
3.459 \\
\end{array}$ & $\begin{array}{c}0.519- \\
0.747 \\
\end{array}$ & $\begin{array}{c}3.524- \\
3.799 \\
\end{array}$ & $\begin{array}{c}2.615- \\
3.281 \\
\end{array}$ & $\begin{array}{l}1.384- \\
2.352 \\
\end{array}$ & $\begin{array}{c}2.160- \\
2.785 \\
\end{array}$ & ND \\
\hline \multirow{2}{*}{ Brand 5} & $\begin{array}{l}\text { mean } \\
\pm \mathrm{SE}\end{array}$ & $\begin{array}{c}1.752 \pm \\
0.250 \\
\end{array}$ & $\begin{array}{c}0.701 \pm \\
0.038 \\
\end{array}$ & $\begin{array}{c}3.635 \pm \\
0.159 \\
\end{array}$ & $\begin{array}{c}1.745 \pm \\
0.156 \\
\end{array}$ & $\begin{array}{c}1.957 \pm \\
0.127 \\
\end{array}$ & $\begin{array}{c}2.719 \pm \\
0.110 \\
\end{array}$ & $\begin{array}{c}0.030 \pm \\
0.023 \\
\end{array}$ \\
\hline & Range & $\begin{array}{l}1.200- \\
2.616\end{array}$ & $\begin{array}{c}0.561- \\
0.792\end{array}$ & $\begin{array}{c}3.074- \\
4.049 \\
\end{array}$ & $\begin{array}{l}1.301- \\
2.189\end{array}$ & $\begin{array}{l}1.548- \\
2.283\end{array}$ & $\begin{array}{l}2.381- \\
3.072 \\
\end{array}$ & $\begin{array}{c}0.000- \\
0.120 \\
\end{array}$ \\
\hline \multirow{2}{*}{ Total samples } & $\begin{array}{l}\text { mean } \\
\pm \mathrm{SE}\end{array}$ & $\begin{array}{c}2.030 \pm \\
0.141 \\
\end{array}$ & $\begin{array}{c}0.653 \pm \\
0.019 \\
\end{array}$ & $\begin{array}{c}3.617 \pm \\
0.042 \\
\end{array}$ & $\begin{array}{c}4.652 \pm \\
0.413 \\
\end{array}$ & $\begin{array}{c}1.954 \pm \\
0.067 \\
\end{array}$ & $\begin{array}{c}2.080 \pm \\
0.116 \\
\end{array}$ & $\begin{array}{c}0.063 \pm \\
0.027 \\
\end{array}$ \\
\hline & Range & $\begin{array}{c}1.144- \\
3.778 \\
\end{array}$ & $\begin{array}{c}0.467- \\
0.792 \\
\end{array}$ & $\begin{array}{c}3.074- \\
4.049 \\
\end{array}$ & $\begin{array}{l}1.301- \\
7.035 \\
\end{array}$ & $\begin{array}{l}1.384- \\
2.352 \\
\end{array}$ & $\begin{array}{c}0.765- \\
3.072 \\
\end{array}$ & $\begin{array}{c}\text { ND- } \\
0.573 \\
\end{array}$ \\
\hline \multicolumn{2}{|l|}{ FAO (1983) } & -------- & -------- & -------- & -------- & $10 \mathrm{ppm}$ & -------- & -------- \\
\hline \multicolumn{2}{|l|}{ WHO (1989) } & -------- & -------- & $\begin{array}{c}60 \\
\text { mg/day }\end{array}$ & -------- & -------- & ------- & ------- \\
\hline \multicolumn{2}{|c|}{ FAO/WHO (1989) } & & -------- & $\begin{array}{c}60 \\
\mathrm{mg} / \mathrm{day} \\
\end{array}$ & ------ & -------- & -------- & ------ \\
\hline \multicolumn{2}{|c|}{ CIFA (1992) } & $0.35 \mathrm{ppm}$ & -------- & -------- & $0.5 \mathrm{ppm}$ & -------- & -------- & -------- \\
\hline \multicolumn{2}{|c|}{ FAO/WHO (1992) } & $0.5 \mathrm{ppm}$ & $0.5 \mathrm{ppm}$ & -------- & -------- & -------- & -------- & -------- \\
\hline \multicolumn{2}{|c|}{ EOSQC (1993) } & -------- & $0.1 \mathrm{ppm}$ & -------- & -------- & -------- & -------- & -------- \\
\hline \multicolumn{2}{|l|}{ EC (2001) } & $0.2 \mathrm{ppm}$ & -------- & -------- & -------- & -------- & -------- & -------- \\
\hline \multicolumn{2}{|c|}{ USEPA (2002) } & -------- & -------- & --------- & -------- & $1 \mathrm{ppm}$ & -------- & $8 \mathrm{ppm}$ \\
\hline \multicolumn{2}{|c|}{$\begin{array}{l}\text { IAEA-407 (Wyse et al., } \\
\text { 2003) }\end{array}$} & $0.12 \mathrm{ppm}$ & $0.19 \mathrm{ppm}$ & -------- & -------- & $0.6 \mathrm{ppm}$ & -------- & $\begin{array}{l}0.73 \\
\mathrm{ppm} \\
\end{array}$ \\
\hline \multicolumn{2}{|l|}{ EOS (2005) } & $0.1 \mathrm{ppm}$ & -------- & & & & & \\
\hline \multicolumn{2}{|l|}{ EU (2005) } & -------- & -------- & -------- & $0.5 \mathrm{ppm}$ & -------- & -------- & -------- \\
\hline \multicolumn{2}{|l|}{ EC (2006) } & $0.3 \mathrm{ppm}$ & $0.1 \mathrm{ppm}$ & -------- & $1 \mathrm{ppm}$ & -------- & -------- & -------- \\
\hline \multicolumn{2}{|l|}{ WHO (2008) } & -------- & ----- & & -------- & $\begin{array}{c}0.5-0.6 \\
\mathrm{ppm}\end{array}$ & ------ & $\begin{array}{c}0.2 \\
\mathrm{ppm}\end{array}$ \\
\hline \multicolumn{2}{|c|}{ Demirel et al. (2008) } & -------- & -------- & $15 \mathrm{ppm}$ & -------- & -------- & -------- & -------- \\
\hline
\end{tabular}


Table 2: The significant difference of metals in the different brands of examined tuna.

\begin{tabular}{|c|c|c|c|c|c|c|c|c|}
\hline Tuna & ands & $\mathbf{P b}$ & Cd & Al & Hg & $\mathrm{Ni}$ & Co & $\mathrm{Cr}$ \\
\hline \multirow{2}{*}{ Brand 1} & $\begin{array}{c}\text { mean } \pm \\
\text { SE }\end{array}$ & $\begin{array}{c}1.984 \pm \\
0.156\end{array}$ & $\begin{array}{c}0.617 \pm \\
0.040\end{array}$ & $\begin{array}{c}3.545 \pm \\
0.017\end{array}$ & $\begin{array}{c}6.640 \pm \\
0.075\end{array}$ & $\begin{array}{c}2.035 \pm \\
0.148\end{array}$ & $\begin{array}{c}1.322 \pm \\
0.149\end{array}$ & $\begin{array}{c}0.246 \pm \\
0.100\end{array}$ \\
\hline & Range & $\begin{array}{l}1.378- \\
2.256\end{array}$ & $\begin{array}{c}0.467- \\
0.696\end{array}$ & $\begin{array}{l}3.510- \\
3.605\end{array}$ & $\begin{array}{l}6.385- \\
6.807\end{array}$ & $\begin{array}{l}1.444- \\
2.202\end{array}$ & $\begin{array}{c}0.765- \\
1.656\end{array}$ & $0.000-0.573$ \\
\hline \multirow{2}{*}{ Brand 2} & $\begin{array}{c}\text { mean } \pm \\
\text { SE }\end{array}$ & $\begin{array}{c}2.581 \pm \\
0.401\end{array}$ & $\begin{array}{c}0.681 \pm \\
0043\end{array}$ & $\begin{array}{l}3.707 \pm \\
0.058\end{array}$ & $5.105 \pm$ & $\begin{array}{c}1.948 \pm \\
0155\end{array}$ & $\begin{array}{c}1.757 \pm \\
0.082\end{array}$ & $0.039 \pm$ \\
\hline & Range & $\begin{array}{l}1.305- \\
3.778\end{array}$ & $\begin{array}{c}0.536- \\
0.778\end{array}$ & $\begin{array}{l}3.500- \\
3.858\end{array}$ & $\begin{array}{l}5.039- \\
5.171\end{array}$ & $\begin{array}{l}1.375- \\
2.302\end{array}$ & $\begin{array}{l}1.515- \\
1.957\end{array}$ & $0.000-0.156$ \\
\hline \multirow{2}{*}{ Brand 3} & $\begin{array}{c}\text { mean } \pm \\
\mathrm{SE} \\
\end{array}$ & $\begin{array}{c}1.804 \pm \\
0.244 \\
\end{array}$ & $\begin{array}{c}0.615 \pm \\
0.041\end{array}$ & $\begin{array}{c}3.525 \pm \\
0.125\end{array}$ & $\begin{array}{l}6.823 \pm \\
0.077 \mathbf{b}\end{array}$ & $\begin{array}{c}1.924 \pm \\
0.159\end{array}$ & $\begin{array}{l}2.089 \pm \\
0.165 \mathbf{a}\end{array}$ & $\begin{array}{c}\text { ND } \\
\mathbf{a}\end{array}$ \\
\hline & Range & $\begin{array}{l}1.190- \\
2.425\end{array}$ & $\begin{array}{c}0.516- \\
0.720\end{array}$ & $\begin{array}{l}3.152- \\
3.938\end{array}$ & $\begin{array}{l}6.611- \\
7.035\end{array}$ & $\begin{array}{l}1.531- \\
2.250\end{array}$ & $\begin{array}{l}1.607- \\
2.525\end{array}$ & ND \\
\hline \multirow{2}{*}{ Brand 4} & $\begin{array}{c}\text { mean } \pm \\
\mathrm{SE}\end{array}$ & $\begin{array}{c}2.030 \pm \\
0.424\end{array}$ & $\begin{array}{c}0.651 \pm \\
0.053\end{array}$ & $\begin{array}{c}3.676 \pm \\
0.044\end{array}$ & $\begin{array}{c}2.948 \pm \\
0.120 \mathbf{a b c}\end{array}$ & $\begin{array}{c}1.906 \pm \\
0.215\end{array}$ & $\begin{array}{c}2.511 \pm \\
0.123 \mathbf{a b}\end{array}$ & $\begin{array}{c}\text { ND } \\
\mathbf{a}\end{array}$ \\
\hline & Range & $\begin{array}{l}1.144- \\
3.459\end{array}$ & $\begin{array}{c}0.519- \\
0.747\end{array}$ & $\begin{array}{l}3.524- \\
3.799\end{array}$ & $\begin{array}{c}2.615- \\
3.281\end{array}$ & $\begin{array}{l}1.384- \\
2.352\end{array}$ & $\begin{array}{c}2.160- \\
2.785\end{array}$ & ND \\
\hline \multirow{2}{*}{ Brand 5} & $\begin{array}{c}\text { mean } \pm \\
\mathrm{SE}\end{array}$ & $\begin{array}{c}1.752 \pm \\
0.250\end{array}$ & $\begin{array}{c}0.701 \pm \\
0.038\end{array}$ & $\begin{array}{c}.635 \pm \\
0.159\end{array}$ & $\begin{array}{c}1.745 \pm \\
0.156 \text { abc }\end{array}$ & $\begin{array}{c}1.957 \pm \\
0.127\end{array}$ & $\begin{array}{c}2.719 \pm \\
0.110 \mathbf{a b c}\end{array}$ & $\begin{array}{l}0.030 \pm \\
0.023 \mathbf{a}\end{array}$ \\
\hline & Range & $\begin{array}{l}1.200- \\
2.616\end{array}$ & $\begin{array}{c}0.561- \\
0.792\end{array}$ & $\begin{array}{l}3.074- \\
4.049\end{array}$ & $\begin{array}{l}1.301- \\
2.189 \\
\end{array}$ & $\begin{array}{l}1.548- \\
2.283 \\
\end{array}$ & $\begin{array}{c}2.381- \\
3.072 \\
\end{array}$ & $0.000-0.120$ \\
\hline \multirow{2}{*}{$\begin{array}{c}\text { Total } \\
\text { samples }\end{array}$} & $\begin{array}{c}\text { mean } \pm \\
\mathrm{SE}\end{array}$ & $\begin{array}{c}2.030 \pm \\
0.141\end{array}$ & $\begin{array}{l}0.653 \pm \\
0.019 \mathbf{a}\end{array}$ & $\begin{array}{c}3.617 \pm \\
0.042 \text { ab }\end{array}$ & $\begin{array}{c}4.652 \pm \\
0.413 \mathbf{a b c}\end{array}$ & $\begin{array}{c}1.954 \pm \\
0.067 \mathrm{bcd}\end{array}$ & $\begin{array}{c}2.080 \pm \\
0.116 \mathrm{bcd}\end{array}$ & $\begin{array}{c}0.063 \pm \\
0.027 \text { acdef }\end{array}$ \\
\hline & Range & $\begin{array}{l}1.144- \\
3.778\end{array}$ & $\begin{array}{c}0.467- \\
0.792\end{array}$ & $\begin{array}{l}3.074- \\
4.049\end{array}$ & $\begin{array}{l}1.301- \\
7.035\end{array}$ & $\begin{array}{l}1.384- \\
2.352\end{array}$ & $\begin{array}{l}0.765- \\
3.072\end{array}$ & ND- 0.573 \\
\hline
\end{tabular}

\section{For the brands:}

a: Means significant from brand 1 at $p \leq 0.05$.

b: Means significant from brand 2 at $\mathrm{p} \leq 0.05$.

c: Means significant from brand 3 at $\mathrm{p} \leq 0.05$.

For the total samples:

a: Means significant difference with $\mathrm{Pb}$ at $\mathrm{p} \leq 0.05$. b: Means significant difference with $\mathrm{Cd}$ at $\mathrm{p} \leq 0.05$. c: Means significant difference with $\mathrm{Al}$ at $\mathrm{p} \leq 0.05$. d: Means significant difference with $\mathrm{Hg}$ at $\mathrm{p} \leq 0.05$.

e: Means significant difference with $\mathrm{Ni}$ at $\mathrm{p} \leq 0.05$. f: Means significant difference with Co at $\mathrm{p} \leq 0.05$.

Table 3: Estimated Daily Intake (EDI, $\mu \mathrm{g} / \mathrm{kg} / \mathrm{day}$ ) of metals in examined canned tuna samples.

\begin{tabular}{|c|c|c|c|c|c|c|c|}
\hline & $\mathbf{P b}$ & Cd & Al & $\mathrm{Hg}$ & $\mathrm{Ni}$ & Co & $\mathrm{Cr}$ \\
\hline Brand 1 & 0.992 & 0.309 & 1.773 & 3.320 & 1.018 & 0.661 & 0.123 \\
\hline Brand 2 & 1.291 & 0.341 & 1.854 & 2.553 & 0.974 & 0.879 & 0.020 \\
\hline Brand 3 & 0.902 & 0.308 & 1.763 & 3.414 & 0.962 & 1.045 & $\mathrm{NE}$ \\
\hline Brand 4 & 1.015 & 0.326 & 1.838 & 1.474 & 0.935 & 1.256 & $\mathrm{NE}$ \\
\hline Brand 5 & 0.876 & 0.351 & 1.818 & 0.874 & 0.979 & 1.360 & 0.015 \\
\hline NRC (1989) & ------- & ------- & ------- & ------ & ------- & 60 & 60 \\
\hline WHO (1989) & ------ & ------ & $60 \mathrm{mg}$ & ------ & ------ & ------ & -----. \\
\hline WHO (1992) & ------- & ------- & ------- & ------- & $100-300$ & ------- & -----.- \\
\hline WHO (2011) & $\begin{array}{c}3.57 \\
\text { Canned tuna }\end{array}$ & $\begin{array}{c}0.833 \\
\text { Canned tuna }\end{array}$ & ------ & ------- & ------- & ------- & ------ \\
\hline CAC (2012) & ------ & 0.833 & ------- & 0.571 & ------- & ------- & $-\cdots-\cdots$ \\
\hline $\begin{array}{c}\text { FAO/WHO } \\
(2013)\end{array}$ & $\begin{array}{ll}----- \\
-1\end{array}$ & 0.833 & ------ & ------ & ------ & ------- & ------ \\
\hline
\end{tabular}

All the values mentioned by agencies and authors were in $\mu \mathrm{g} / \mathrm{kg} /$ day. 
Table 4: EWI ( $\mu \mathrm{g} / \mathrm{kg} /$ week) of metals in examined canned tuna samples.

\begin{tabular}{|c|c|c|c|c|c|c|c|}
\hline & $\mathbf{P b}$ & Cd & Al & $\mathrm{Hg}$ & $\mathrm{Ni}$ & Co & $\mathbf{C r}$ \\
\hline Brand 1 & 6.944 & 2.163 & 12.411 & 23.240 & 7.126 & 4.627 & 0.861 \\
\hline Brand 2 & 9.037 & 2.387 & 12.978 & 17.871 & 6.818 & 6.153 & 0.140 \\
\hline Brand 3 & 6.314 & 2.156 & 12.341 & 23.898 & 6.734 & 7.313 & $\mathrm{NE}$ \\
\hline Brand 4 & 7.105 & 2.282 & 12.866 & 10.318 & 6.545 & 8.792 & $\mathrm{NE}$ \\
\hline Brand 5 & 6.132 & 2.457 & 12.726 & 6.118 & 6.853 & 9.520 & 0.105 \\
\hline NRC (1989) & ------ & ------ & ------ & ----- & ------ & 420 & 420 \\
\hline WHO (1989) & ------- & ------ & $420 \mathrm{mg}$ & ------ & ------- & ------- & ------ \\
\hline WHO (1992) & ------- & ------- & ------- & ------ & $700-2100$ & ------ & ------ \\
\hline WHO (2000) & 25 & ------- & ------- & ----- & ------- & ----- & ------ \\
\hline FAO/WHO (2003) & 25 & 5.833 & ------ & 5 & ------ & ------ & ------ \\
\hline WHO (2006) & 25 & ------- & ------- & ------ & ------- & ------ & ------- \\
\hline FAO/WHO (2011) & 25 & 5.833 & ------- & ------ & ------- & ------ & ------- \\
\hline CAC (2012) & ------ & 5.833 & ------ & 4 & ------ & ----- & ----- \\
\hline FAO/WHO (2013) & ------- & 5.833 & ------- & ------- & ------- & ------ & ------ \\
\hline
\end{tabular}

All the values mentioned by agencies and authors were in $\mu \mathrm{g} / \mathrm{kg} / \mathrm{week}$.

Table 5: EWI/Provisional Tolerable Weekly Intake (PTWI) ratio of metals in examined tuna.

\begin{tabular}{cccccccc}
\hline & Pb & Cd & Al & Hg & Ni & Co & Cr \\
\hline Brand 1 & 0.278 & 0.309 & $2.954 \times 10^{-5}$ & 4.648 & $10.175 \times 10^{-3}$ & 0.011 & $2.50 \times 10^{-3}$ \\
\hline Brand 2 & 0.361 & 0.341 & $3.089 \times 10^{-5}$ & 3.574 & $9.740 \times 10^{-3}$ & 0.015 & $3.25 \times 10^{-4}$ \\
\hline Brand 3 & 0.253 & 0.308 & $2.937 \times 10^{-5}$ & 4.779 & $9.620 \times 10^{-3}$ & 0.017 & $\mathrm{NE}$ \\
\hline Brand 4 & 0.284 & 0.326 & $3.063 \times 10^{-5}$ & 2.064 & $9.345 \times 10^{-3}$ & 0.020 & $\mathrm{NE}$ \\
\hline Brand 5 & 0.245 & 0.351 & $3.029 \times 10^{-5}$ & 1.224 & $9.785 \times 10^{-3}$ & 0.023 & $2.50 \times 10^{-4}$ \\
\hline
\end{tabular}

Table 6: Target Health Quotient (THQ) (mg/kg) of metals in examined canned tuna.

\begin{tabular}{|c|c|c|c|c|c|c|c|c|}
\hline & & $\mathbf{P b}$ & Cd & Al & Hg & $\mathbf{N i}$ & Co & $\mathrm{Cr}$ \\
\hline \multicolumn{2}{|c|}{ Brand 1} & 0.248 & 0.309 & 0.00177 & 11.067 & 0.051 & 0.033 & 0.000082 \\
\hline \multicolumn{2}{|c|}{ Brand 2} & 0.323 & 0.341 & 0.00185 & 8.510 & 0.049 & 0.044 & 0.000013 \\
\hline \multicolumn{2}{|c|}{ Brand 3} & 0.226 & 0.308 & 0.00176 & 11.380 & 0.048 & 0.052 & $\mathrm{NE}$ \\
\hline \multicolumn{2}{|c|}{ Brand 4} & 0.254 & 0.326 & 0.00184 & 4.913 & 0.047 & 0.063 & $\mathrm{NE}$ \\
\hline \multicolumn{2}{|c|}{ Brand 5} & 0.219 & 0.351 & 0.00182 & 2.913 & 0.049 & 0.068 & 0.00001 \\
\hline \multirow[t]{2}{*}{$\begin{array}{l}\text { Total } \\
\text { brands }\end{array}$} & $\begin{array}{l}\text { Min- } \\
\text { Max. }\end{array}$ & $\begin{array}{c}0.219- \\
0.323\end{array}$ & $\begin{array}{c}0.308- \\
0.351\end{array}$ & $\begin{array}{c}0.00176- \\
0.00185\end{array}$ & $\begin{array}{l}2.913- \\
11.380\end{array}$ & $\begin{array}{l}0.047- \\
0.051\end{array}$ & $\begin{array}{l}0.033- \\
0.049\end{array}$ & $\begin{array}{c}0.0001- \\
0.000082\end{array}$ \\
\hline & $\begin{array}{l}\text { Mean } \\
\pm \text { SE }\end{array}$ & $\begin{array}{c}0.254 \pm \\
0.016\end{array}$ & $\begin{array}{c}0.327 \pm \\
0.008\end{array}$ & $\begin{array}{c}0.00181 \pm \\
0.00001\end{array}$ & $\begin{array}{c}7.757 \pm \\
1.499\end{array}$ & $\begin{array}{c}0.049 \pm \\
0.001\end{array}$ & $\begin{array}{c}0.052 \pm \\
0.001\end{array}$ & $\begin{array}{c}0.000035 \pm \\
0.000014\end{array}$ \\
\hline
\end{tabular}

Hazard Health Index (HI) for brand 1= 11.709, HI for brand 2=9.268, HI for brand 3= 12.015, HI for brand $4=5.604$, HIfor brand $5=3.601$ 
Table 7: Correlation between determined heavy metal in different analyzed canned tuna.

\begin{tabular}{|c|c|c|c|c|c|c|c|c|}
\hline & & $\mathbf{P b}$ & Cd & Al & $\mathrm{Hg}$ & $\mathbf{N i}$ & Co & $\mathrm{Cr}$ \\
\hline \multirow{7}{*}{ Brand 1} & $\mathbf{P b}$ & ---- & -0.205 & -0.030 & -0.297 & -0.089 & -0.013 & 0.089 \\
\hline & $\mathbf{C d}$ & & |----- & 0.598 & -0.248 & 0.932 & 0.809 & -0.598 \\
\hline & $\mathbf{A l}$ & & & - ----י & -0.558 & 0.344 & 0.355 & 0.031 \\
\hline & $\mathrm{Hg}$ & & & & ----- & 0.025 & 0.241 & -0.557 \\
\hline & $\mathrm{Ni}$ & & & & & ------ & 0.932 & -0.830 \\
\hline & Co & & & & & & $\begin{array}{ll}----- \\
\end{array}$ & -0.917 \\
\hline & $\mathrm{Cr}$ & & & & & & & ------ \\
\hline \multirow{7}{*}{ Brand 2} & $\mathbf{P b}$ & ----- & 0.792 & 0.118 & -0.740 & 0.679 & 0.304 & 0.772 \\
\hline & Cd & & ------ & 0.276 & -0.531 & 0.912 & 0.427 & 0.578 \\
\hline & $\mathbf{A l}$ & & & ------ & 0.052 & -0.119 & -0.727 & 0.674 \\
\hline & $\mathrm{Hg}$ & & & & ------ & -0.489 & -0.291 & -0.510 \\
\hline & $\mathrm{Ni}$ & & & & & ------ & 0.758 & 0.235 \\
\hline & Co & & & & & & $\begin{array}{l}----- \\
-1\end{array}$ & -0.354 \\
\hline & $\mathrm{Cr}$ & & & & & & & ב----- \\
\hline \multirow{7}{*}{ Brand 3} & $\mathbf{P b}$ & ------ & 0.426 & 0.746 & -0.945 & 0.586 & 0.466 & ND \\
\hline & $\mathbf{C d}$ & & ------ & 0.816 & -0.484 & 0.877 & 0.909 & $\mathrm{ND}$ \\
\hline & $\mathbf{A l}$ & & & $\begin{array}{l}----- \\
-\cdots\end{array}$ & -0.872 & 0.665 & 0.677 & $\mathrm{ND}$ \\
\hline & $\mathrm{Hg}$ & & & & ------ & -0.486 & -0.425 & $\mathrm{ND}$ \\
\hline & $\mathrm{Ni}$ & & & & & ----- & 0.952 & ND \\
\hline & Co & & & & & & '----- & ND \\
\hline & $\mathrm{Cr}$ & & & & & & & ------ \\
\hline \multirow{7}{*}{ Brand 4} & $\mathbf{P b}$ & ------- & 0.348 & 0.371 & -0.134 & -0.313 & -0.107 & ND \\
\hline & $\overline{C d}$ & & ------ & 0.665 & -0.290 & 0.964 & \begin{tabular}{c|}
0.958 \\
\end{tabular} & $\mathrm{ND}$ \\
\hline & $\mathbf{A l}$ & & & ------ & -0.295 & 0.757 & 0.756 & $\mathrm{ND}$ \\
\hline & $\mathrm{Hg}$ & & & & ני----- & -0.270 & -0.460 & $\mathrm{ND}$ \\
\hline & $\mathrm{Ni}$ & & & & & - ------ & 0.908 & $\mathrm{ND}$ \\
\hline & Co & & & & & & $\begin{array}{l}----- \\
\end{array}$ & ND \\
\hline & $\mathrm{Cr}$ & & & & & & & 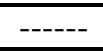 \\
\hline \multirow{7}{*}{ Brand 5} & $\mathbf{P b}$ & ----- & 0.478 & 0.311 & -0.323 & 0.136 & 0.937 & 0.895 \\
\hline & Cd & & ------ & 0.681 & 0.056 & 0.935 & 0.661 & 0.129 \\
\hline & $\mathbf{A l}$ & & & ------ & -0.612 & 0.636 & 0.522 & 0.169 \\
\hline & $\mathrm{Hg}$ & & & & ב---- & 0.205 & -0.388 & -0.536 \\
\hline & $\mathrm{Ni}$ & & & & & ------ & 0.363 & -0.222 \\
\hline & Co & & & & & & - ----- & 0.828 \\
\hline & $\mathrm{Cr}$ & & & & & & & ------ \\
\hline \multirow{7}{*}{ Total brands } & $\mathbf{P b}$ & ------ & 0.206 & 0.349 & 0.041 & 0.135 & -0.066 & 0.142 \\
\hline & Cd & & $\begin{array}{l}----- \\
\end{array}$ & 0.555 & -0.315 & 0.848 & 0.508 & -0.200 \\
\hline & $\mathbf{A l}$ & & & ------ & -0.268 & 0.370 & 0.275 & 0.047 \\
\hline & $\mathrm{Hg}$ & & & & $\begin{array}{ll}---- \\
\end{array}$ & 0.037 & -0.749 & 0.291 \\
\hline & $\mathrm{Ni}$ & & & & & $\begin{array}{ll}----- \\
\end{array}$ & 0.278 & -0.126 \\
\hline & Co & & & & & & ------ & -0.606 \\
\hline & $\mathrm{Cr}$ & & & & & & & ----- \\
\hline
\end{tabular}

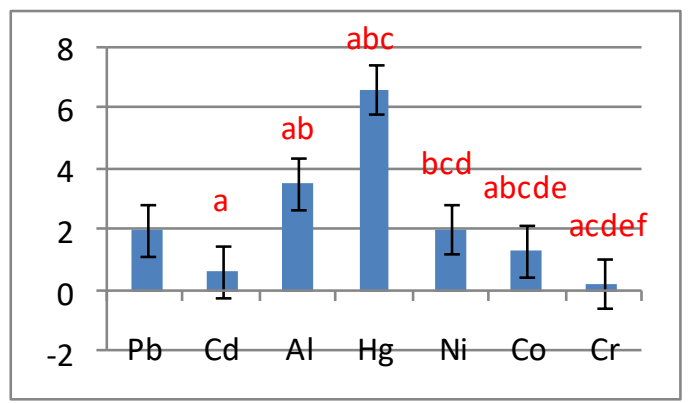

Fig. 1

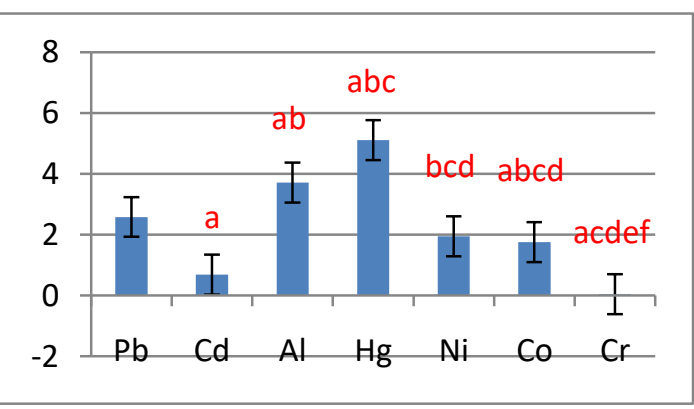

Fig. 2 


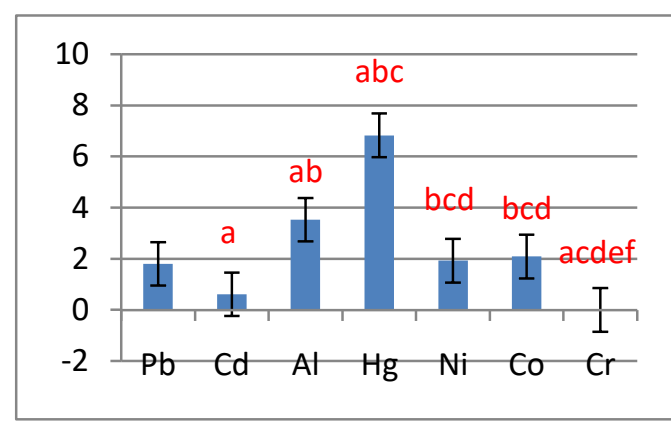

Fig. 3

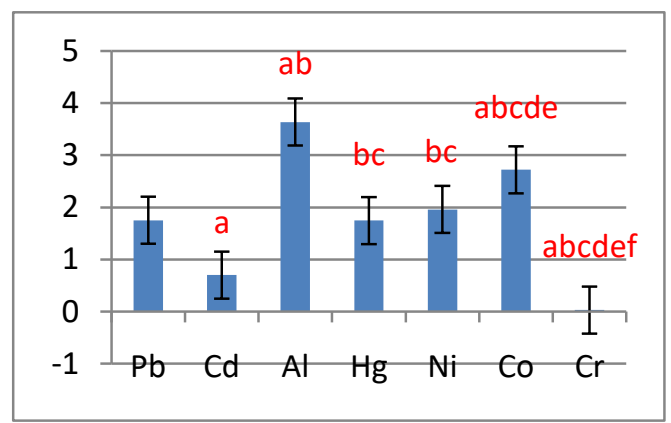

Fig. 5

Figure 1: Showing the concentrations (ppm) of metals in the samples of canned tuna in the brand 1 .

Figure 2: Showing the concentrations (ppm) of metals in the samples of canned tuna in the brand 2 .

Figure 3: Showing the concentrations (ppm) of metals in the samples of canned tuna in the brand 3 .

Figure 4: Showing the concentrations (ppm) of metals in the samples of canned tuna in the brand 4 .

Figure 5: Showing the concentrations (ppm) of metals in the samples of canned tuna in the brand 5 .

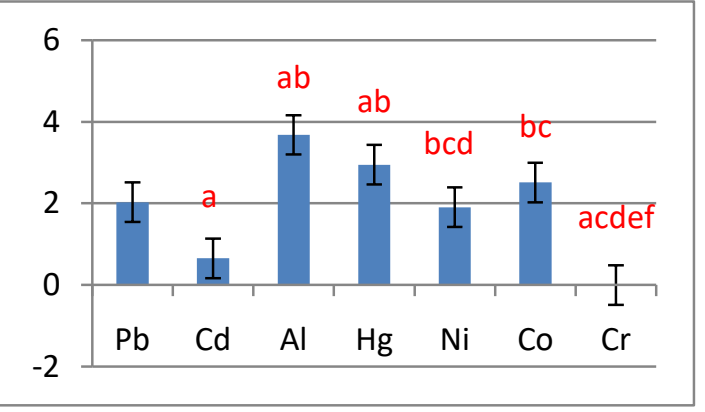

Fig. 4

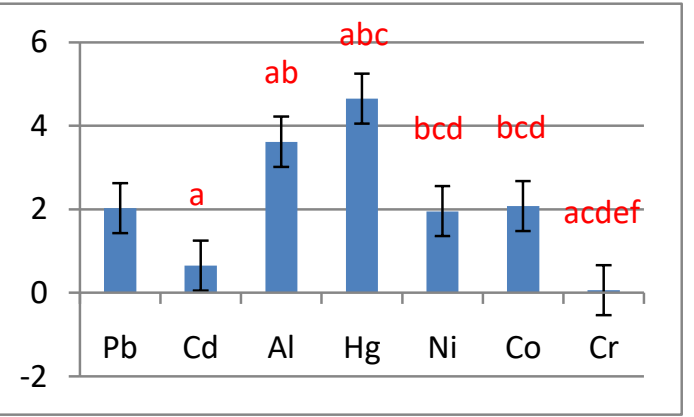

Fig. 6

Figure 6: Showing the concentrations (ppm) of metals in the total samples of canned tuna in all brands.

a: means significant difference with $\mathrm{Pb}$ at $\mathrm{p} \leq 0.05$.

b: means significant difference with $C d$ at $p \leq 0.05$.

c: means significant difference with $\mathrm{Al}$ at $\mathrm{p} \leq 0.05$.

d: means significant difference with $\mathrm{Hg}$ at $\mathrm{p} \leq 0.05$.

e: means significant difference with $\mathrm{Ni}$ at $\mathrm{p} \leq 0.05$.

f: means significant difference with $C o$ at $p \leq 0.05$.

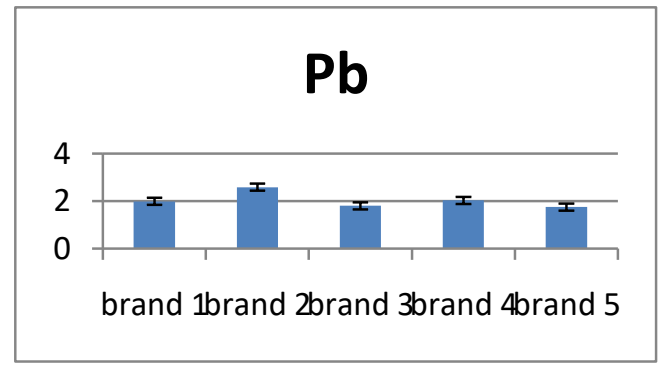

Fig. 7

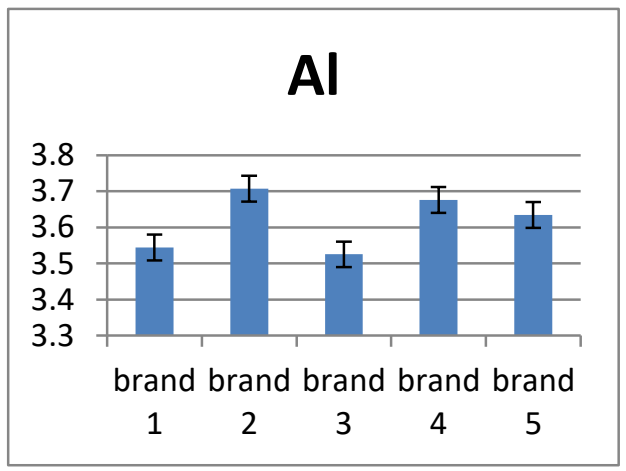

Fig. 9

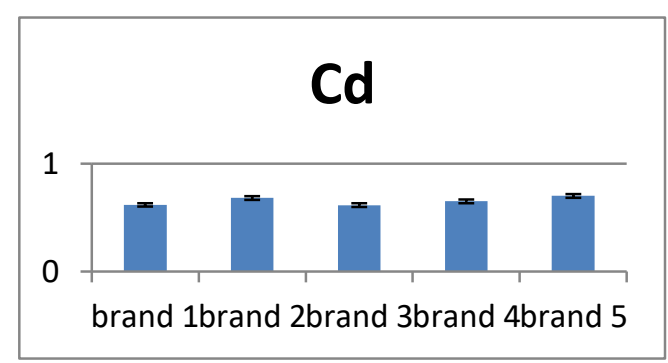

Fig. 8

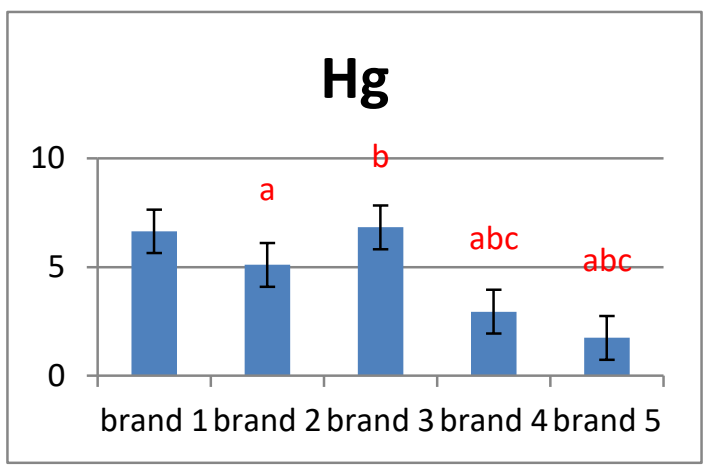

Fig. 10 


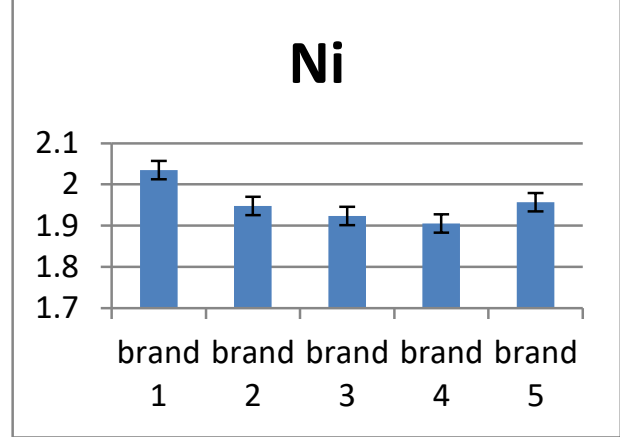

Fig. 11

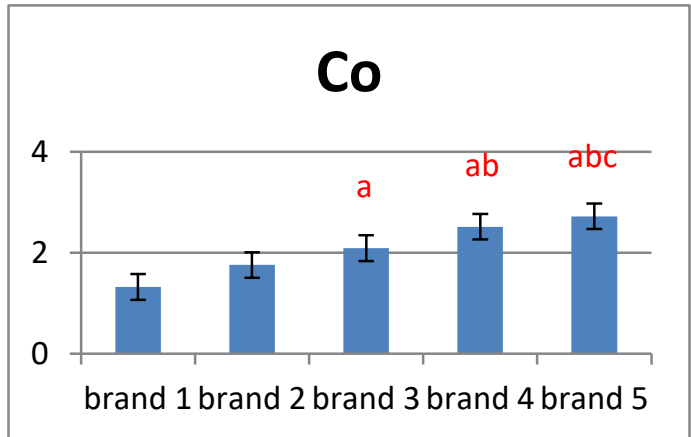

Fig. 12

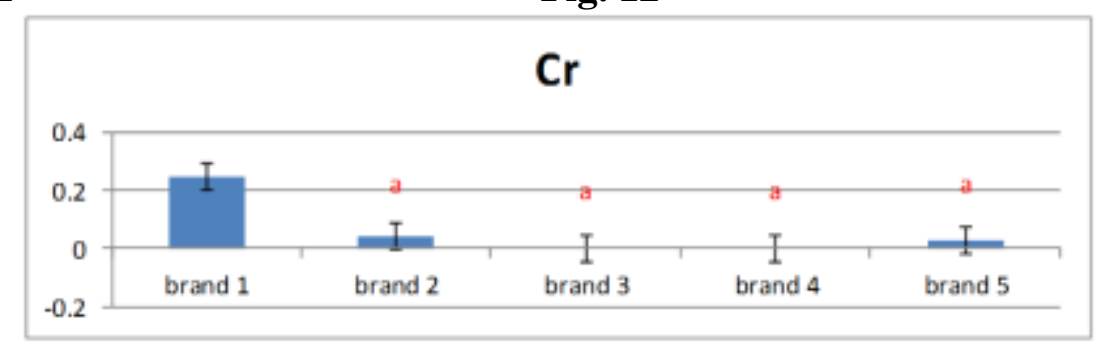

Fig. 13

Figure 7: The concentrations (ppm) of $\mathrm{Pb}$ in the samples of canned tuna in all brands.

Figure 8: The concentrations (ppm) of $\mathrm{Cd}$ in the samples of canned tuna in all brands.

Figure 9: The concentrations (ppm) of $\mathrm{Al}$ in the samples of canned tuna in all brands.

Figure 10: The concentrations (ppm) of $\mathrm{Hg}$ in the samples of canned tuna in all brands.
Figure 11: The concentrations (ppm) of $\mathrm{Ni}$ in the samples of canned tuna in all brands.

Figure 12: The concentrations (ppm) of $\mathrm{Co}$ in the samples of canned tuna in all brands.

Figure 13: The concentrations (ppm) of $\mathrm{Cr}$ in the samples of canned tuna in all brands.

a: Means significant from brand 1 at $\mathrm{p} \leq 0.05$.

b: Means significant from brand 2 at $p \leq 0.05$.

c: Means significant from brand 3 at $\mathrm{p} \leq 0.05$.

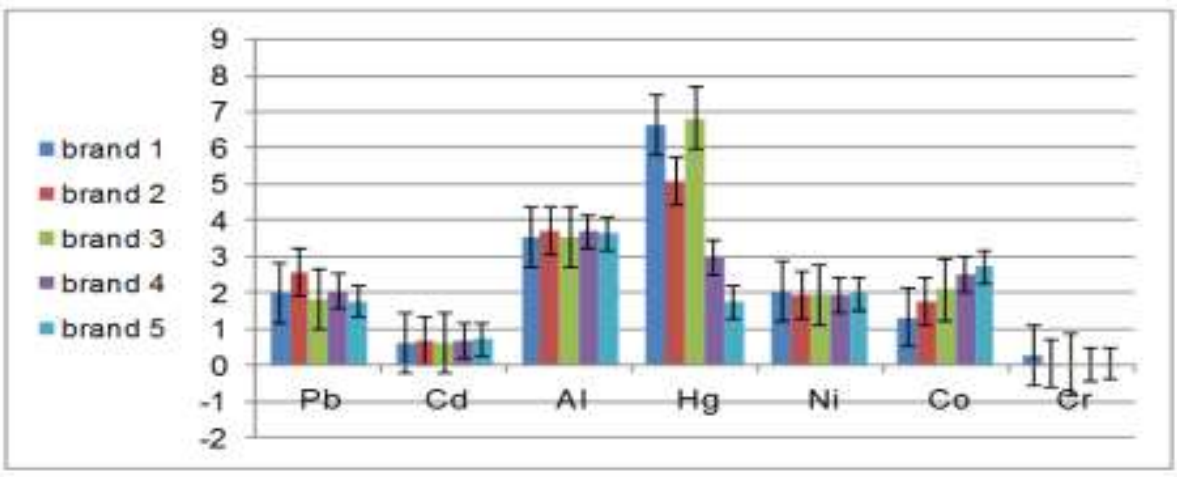

Figure 14: The concentrations (ppm) of metal in the samples of canned tuna in all brands.

\section{DISCUSSION}

When heavy metals pollute the aquatic environment induce health hazards due to the accumulation of these pollutants in fish. Fish are more sensitive to pollutants than invertebrates, so it is a good indicator for detection of aquatic pollution (Moiseenko et al., 2008 and Mendil et al., 2010). The organisms in the aquatic environment exposed to high amounts of metals via gills either from the contaminated water or feed and accumulate these pollutants inside the fish tissues. These pollutants reach to the human upon consumption of these polluted fish resulting in many health troubles and toxicities to the human (Ahmad and Othman, 2010).

[1] Lead: Lead concentrations (ppm) in all examined canned tuna samples in the five brands were $1.984 \pm 0.156 \quad(1.378-2.256), \quad 2.581 \pm 0.401$ (1.305-3.778), $\quad 1.804 \pm 0.244 \quad(1.190-2.425)$, $2.030 \pm 0.424$ (1.144-3.459), $1.752 \pm 0.250 \quad(1.200$ 2.616) respectively, while in total samples was $2.030 \pm 0.141$ (1.144-3.778) (table1, figures 1-5). 
All these levels of $\mathrm{Pb}$ were higher than the maximum acceptable limits (ppm) recommended by different authorities and agencies such as CIFA (1992) as 0.35 in canned fish; FAO/WHO (1992) as 0.5 in fish, EC (2001) as 0.2 in canned fish, IAEA-407 (Wyse et al., 2003) as 0.12; EOS (2005) as $0.1 \mathrm{mg} / \mathrm{kg}$ and EC (2006) as $0.3 \mathrm{mg} / \mathrm{kg}$. So, consumption of large amounts of these canned tuna for long time can cause adverse health effects in the consumers.

Lead values $(\mathrm{mg} / \mathrm{kg}$ wet weight) recorded in this study in examined canned tuna were higher than that reported by other literatures as $0.18-0.40$ in Libya (Voegborlo et al., 1999), 1.985 in Egypt (Abdelgwad 2003); 0.0-0.03 in USA (Ikem and Egiebor, 2005), 0.002-0.84 in Saudi Arabia (Ashraf, 2006), 0.076-0.314 in Turkey (Celik and Oehlenschlager, 2007), 0.09-0.40 in Turkey (Tuzen, 2007), 0.329-0.537 (average 0.337) in Egypt (Ahdy et al., 2009), 0.007-0.51 (average 0.0746) in Iran (Zarei et al., 2010), 0.06 in Italy (Storelli et al., 2010), 0.15 in Iran (Ganjavi et al., 2010), 0.11-0.30 in Iran (Malakootian et al., 2011), 0.09-0.45 in Turkey (Mol, 2011), 0.011-0.089 in India (Canadian and Indian made tuna) (Mahalakshmi et al., 2012), 0.011 in Canadian canned tuna and 0.089 in Indian canned tuna (Kumar et al., 2013), 0.127 in Egypt (Morshady et al., 2013), 0.016-0.310 (average 0.162) in canned skipjack Tuna Fish (Sika et al., 2014), 0.01-0.242 in Tabriz (Iran) (Pourjafar et al., 2014), 0.01-0.27 (average 0.13) in one brand and 0.02-0.44 (average 0.19) in the other brand in Egypt (Saad et al., 2014), 0.346 in India (Dhaneesh et al., 2014), 0.030.60 (average 0.239 ) in canned skipjack tuna in Libya (Abolghait and Garbaj, 2015), 0.00430.0856 (average 0.0201) in Morocco (Adil et al., 2015) and <0.001-0.010 in Italy (Pappalardo et al., 2017).

The estimated weekly intake $(\mu \mathrm{g} / \mathrm{kg}$ bw/week) values for $\mathrm{Pb}$ in this study in the examined canned tuna from the five brands were as following 6.944, $9.037,6.314,7.105$ and 6.132 respectively (table 4). These estimated values were lower than that recommended by FAO/WHO (2003, 2011); WHO $(2000,2006)$ as $25 \mu \mathrm{g} / \mathrm{kg}$ bw/week. The provisional tolerable intake for $\mathrm{Pb}$ is suggested as 3 $\mathrm{mg} / \mathrm{kg}$ by FAO and WHO while The maximum level of lead in the food that admitted to children or babies is $200 \mu \mathrm{g} / \mathrm{kg}$ (CIFA, 1992).. For children under 6 years or pregnant or nursing women, consumption of one can per week do not induce a problem for them (Zhou et al., 1998).

The high levels of $\mathrm{Pb}$ in these examined tuna may be attributed to the contamination of fish as a result of increased mining activities, discharges of wastes either industrial or agricultural into the water streams. These high levels of $\mathrm{Pb}$ when consumed for long time can lead to severe adverse effects to the consumers.

$\mathrm{As} \mathrm{Pb}$ causes many health hazards, inorganic $\mathrm{Pb}$ compounds have been classified as carcinogenic for group 2A humans (related mainly to the stomach cancer) while $\mathrm{Pb}$ classified as carcinogenic for group 2B humans (IARC, 2014).

[2] Cadmium: Cd concentrations (ppm) in all examined canned tuna samples in the five brands were $0.617 \pm 0.04 \quad(0.467-0.696), \quad 0.681 \pm 0.043$ (0.536-0.778), $\quad 0.615 \pm 0.041 \quad(0.516-0.720)$, $0.651 \pm 0.053(0.519-0.747), 0.701 \pm 0.038$ (0.561$0.792)$ respectively, while in total samples was $0.653 \pm 0.019$ (0.467-0.792) (table1, figures 1-5). All these concentrations of $\mathrm{Cd}$ were higher than the maximum acceptable limits (ppm) recommended by different authorities and agencies such as FAO/WHO (1992) as 0.5 in fish, EOSQC (1993) as 0.1 in fish, IAEA-407 (Wyse et al., 2003) as 0.19 and EC (2006) as 0.1. From these obtained results, eating more of this type of canned tuna can result in health problems in human.

The estimated weekly intake $(\mu \mathrm{g} / \mathrm{kg} \mathrm{BW} /$ week) for $\mathrm{Cd}$ in this study in the examined canned tuna from the five brands were as following 2.163, 2.387, $2.156,2.282$ and 2.457 respectively (table 4). These estimated values were lower than that permitted by FAO/WHO $(2003,2011)$ as 7 and CAC (2012) and FAO/WHO (2013) as $5.33 \mu \mathrm{g} / \mathrm{kg}$ bw/week.

$\mathrm{Cd}$ values ( $\mathrm{mg} / \mathrm{kg}$ wet weight) in this study in examined canned tuna were higher than that reported by other literatures as 0.09-0.32 (with average 0.18) in Libya (Voeghorlo et al., 1999), 0.0046-0.0720 (0.022) in canned tuna fish in Iran (Emami-Khansari et al., 2005), 0.0-0.05 in canned fish (Ikem and Egiebor, 2005), 0.16 (0.08-0.66) in Saudi Arabia (Ashraf, 2006), 0.025-0.494 in Turkey (Celik and Oehlenschlager, 2007), 0.060.25 from Turkey (Tuzen, 2007), 0.169-0.181 (average 0.173) in Egypt (Ahdy et al., 2009), 0.002-0.070 (0.0246) in Iran (Zarei et al., 2010), 0.04 in Italy (Storelli et al., 2010), 0.01-0.02 in Turkey (Mol, 2011), 0.05 to 0.16 (0.3519) in Iran (Malakootian et al., 2011), <0.001 in Ghana (Boadi et al., 2011), 0.020-0.025 in canned tuna fish in India (Canadian and Indian made tuna)( Mahalakshmi et al., 2012), 0.020 in Canadian canned tuna and 0.025 in Indian canned tuna (Kumar et al., 2013), 0.022 in Egypt (Morshdy et al., 2013), 0.002-0.0.092 (0.015) in canned skipjack Tuna Fish (Sika et al., 2014), 0.03-0.12 in Tehran (Iran) (Fathabad et al., 2015), 0.079 (0.010.19) in canned skipjack tuna (Abolghait and Garbaj, 2015), 0.0032-0.0834 (0.0295) in Morocco 
(Adil et al., 2015); and 0.010-0.060 for canned tuna with olive oil in Italy and <0.003-0.030 in canned tuna with brine (Pappalardo et al., 2017).

High $\mathrm{Cd}$ concentration in the water sediments is reflected in $\mathrm{Cd}$ content of prey (Eisler, 2010). Biomagnification of $\mathrm{Cd}$ in muscle of predator fish such as skipjack (average concentration 0.23 $\mathrm{mg} / \mathrm{kg} \mathrm{dw}$ ) is depending on the function of the trophic position (Ruelas-Inzunza et al., 2014). Cd occurs naturally at low levels in the environment. Industrial processes can increase the concentration of $\mathrm{Cd}$ in the environment (Ahmed et al., 2015).

$\mathrm{Cd}$ accumulated in the human tissues can induce infertility, skeletal damage, renal dysfunction and lung fibrosis (ATSDR, 2012). Cd is classified as carcinogen for group 1 humans especially for cancers in kidneys, prostate, pancreas, bladder and lung (IARC, 2014).

[3] Aluminum: Al concentrations (ppm) in all examined canned tuna in the five brands were

$3.545 \pm 0.017$ (3.510-3.605), 3.707 \pm 0.058 (3.500$3.858), \quad 3.525 \pm 0.125(3.152-3.938), \quad 3.676 \pm 0.044$ (3.524-3.799), $\quad 3.635 \pm 0.159 \quad(3.074-4.049)$ respectively, while in total samples was $3.617 \pm 0.042$ (3.074-4.049) (table1, figures 1-5). These results were lower than that mentioned by WHO (1989), FAO/WHO (1989) as they set a limit of $60 \mathrm{mg}$ per day is the MPL for Al; and Demirel et al. (2008) who found $\mathrm{Al}$ level in some foods as 15 $\mathrm{mg} / \mathrm{kg}$.

The $\mathrm{Al}$ values $(\mathrm{mg} / \mathrm{kg}$ wet weight) recorded in this study in examined canned were higher than that reported by other literatures as Mahalakshmi et al. (2012) who found Al content in examined canned tuna fish in India (Canadian and Indian made tuna) was $(1.806$ to $3.161 \mu \mathrm{g} / \mathrm{g})$, Kumar et al. (2013) found that $\mathrm{Al}$ level $(\mu \mathrm{g} / \mathrm{g})$ was 1.806 in Canadian canned tuna and 3.161 in Indian canned tuna, while Dhaneesh et al. (2014) found Al content in different types of canned tuna in India was $15.96 \pm$ $0.625 \mathrm{ug} / \mathrm{g}$, while in muscles of fresh fish was $10.69 \pm 0.498 \mathrm{ug} / \mathrm{g}$. Al content in canned fish samples from Tehran (Iran) were $(\mu \mathrm{g} / \mathrm{g})$ 0.49-2.15 (Fathabad et al., 2015), 0.032-5.346 $\mu \mathrm{g} / \mathrm{g}$ wet weight in fish fillets baked and grilled in Al foil (Ranau et al., 2001), Turkmen et al. (2005), Al content was $0.02-5.41 \mu \mathrm{g} / \mathrm{g}$ dry weight in fish species from Iskenderum Bey, northern east Mediterranean sea, Turkey.

The estimated weekly intake $(\mu \mathrm{g} / \mathrm{kg}$ bw/week) values for $\mathrm{Al}$ in this study in the samples examined canned tuna from the five brands were as following $12.411,12.978,12.341,12.866$ and 12.726 respectively (table 4). These estimated values were lower than that permitted by WHO (1989) as the maximum acceptable weekly intake is $420 \mathrm{mg}$.
[4] Mercury: Mercury contents (ppm) in examined canned tuna in the five brands were $6.640 \pm 0.075$ (6.385-6.807), $\quad 5.105 \pm 0.025 \quad$ (5.039-5.171), $6.823 \pm 0.077$ (6.611-7.035), 2.948 $\pm 0.120 \quad$ (2.615$3.281), \quad 1.745 \pm 0.156$ (1.301-2.189) respectively, while in total samples was $4.652 \pm 0.413$ (1.3017.035) (table1, figures 1-5). All these concentrations of $\mathrm{Hg}$ were higher than the maximum acceptable limits ( $\mathrm{ppm}$ ) recommended by different authorities and agencies such as CIFA (1992) as 0.5 in canned fish, EU (2005) as 0.5 and EC (2006) as 1 in fish. High Hg content in these examined canned tuna can represent a risk health effects for the consumers if eaten for long periods.

$\mathrm{Hg}$ values ( $\mathrm{mg} / \mathrm{kg}$ wet weight) recorded in this study in examined canned were higher than that reported by other literatures as $0.29(0.20-0.66)$ tuna in Libya (Voegborlo et al., 1999), 0.04300.253 in Iran (Khansari et al., 2005), 0.18-0.86 in Saudi Arabia (Ashraf, 2006), 0.01-0.24 in canned fish (Islam et al., 2010), 0.102-0.400 in Ghana (Boadi et al., 2011), 0.06- 0.30 in Turkish canned tuna (Mol, 2011), 0.26 in Mexico (Ruelas-Inzunza et al., 2011), 0.023-0.529 (0.146) in Iran (Rahimi and Behzadnia, 2011), 0.60 in Canadian canned tuna and $0.62 \mu \mathrm{g} / \mathrm{g}$ in Indian made canned tuna (Mahalakshmi et al., 2012), 0.60 in Canadian canned tuna and 0.62 in Indian canned tuna (Kumar et al., 2013), 0.1-0.205 in Tabriz (Iran) (Pourjafar et al., 2014), 0.09-1.02 (0.49) in brand A and 0.13-1.25 (0.57) in the brand B (Saad et al., 2014), 0.085 in different types of canned tuna in India (Dhaneesh et al., 2014), 0.03-0.12 in different brands of canned tuna (Fathabad et al., 2015), 0.373 (0.08-0.75) (Abolghait and Garbaj, 2015), 0.0378- 0.5243 (0.2087) (Adil et al., 2015), $0.170-0.240$ incanned tuna with olive oil and 0.060-0.480 in canned tuna with brine in Italy (Pappalardo et al., 2017).

The estimated weekly intake $(\mu \mathrm{g} / \mathrm{kg} \mathrm{BW} /$ week) for $\mathrm{Hg}$ in this study in the samples examined canned tuna from the five brands were as following $23.240, \quad 17.871, \quad 23.898, \quad 10.318$ and 6.118 respectively. These estimated values were higher than that permitted by FAO/WHO (2003) as 5 and CAC (2012) as $4 \mu \mathrm{g} / \mathrm{kg}$ bw/week.

All the examined tuna samples showed that $\mathrm{Hg}$ levels were higher than acceptable limit as 0.5 $\mathrm{mg} / \mathrm{kg}$ (FAO, 1983 and EU, 2005). These levels of $\mathrm{Hg}$ can result in effects on the kidneys and on the developing fetus. Mercury is categorized as a possible human carcinogen (Occupational Safety and Health Administration, 2004).

Canned tuna consists of large species of tuna (e.g. albacore and yellowfin tuna), contains moderate 
amounts of $\mathrm{Hg}$, whereas, canned tuna consists of smaller species (e.g. skipjack), contains around one-third the $\mathrm{Hg}$ level of albacore and yellowfin tuna (Bratt, 2010). In heavily polluted marine areas the concentrations of $\mathrm{Hg}$ in the muscle of the fish is above the permissible limits for human consumption and accompanied with severe health disorders (Denton and Burdon-Jones, 1986; Chen et al., 2014). Kehrig et al. (1998), Havelková et al. (2008) and Farkas et al. (2003) recorded that metals concentration in fish muscle can be detected in areas with low or absent sources of pollution.

[5] Nickel: Nickel concentrations (ppm) in all examined canned tuna in the five brands were

$2.035 \pm 0.148 \quad(1.444-2.202), 1.948 \pm 0.155 \quad(1.375$ 2.302), $1.924 \pm 0.159$ (1.531-2.250), $1.906 \pm 0.215$ (1.384-2.352), $\quad 1.957 \pm 0.127 \quad(1.548-2.283)$ respectively, while in total samples was $1.954 \pm 0.067$ (1.384-2.352) (table1, figures 1-5). All these concentrations of $\mathrm{Ni}$ were higher than the maximum acceptable limits (ppm) recommended by different authorities and agencies such as IAEA-407 (Wyse et al., 2003) as 0.6 and WHO (2008) as 0.5-0.6 in fish, while lower than that permitted by USEPA (2002) as $1 \mathrm{ppm}$, but lower than that proposed by FAO (1983) as the MPL of $\mathrm{Ni}$ in fish species is about $10 \mathrm{mg} / \mathrm{kg}$.

The Ni values ( $\mathrm{mg} / \mathrm{kg}$ wet weight) recorded in this study in examined canned were higher than that reported by other literatures as $0.0-0.78$ in canned fish (Ikem and Egiebor, 2005), 0.09-0.48 mg/kg (0.16) in Saudi Arabia (Ashraf, 2006), 0.36 in USA, 0.26 in Thailand, and 0.12 in Korea (Islam et al., 2010), 0.0-0.78 in canned fish (Morgano et al., 2011), 0.50-0.85 in canned fish from Turkey (Tuzen, 2007), 0.992-1.236 in examined canned tuna fish market in Egypt (Ahdy et al., 2009), was 0.04-3.26 in Nigeria (Iwegbue et al., 2009), 0.0.271-2.600 in Egypt (El-Sadaawy et al., 2011), 0.14-0.7 (0.24) in southern of Iran (Malakootian et al., 2011), 0.065 in India (Dhaneesh et al., 2014), 0.113-0.589 in Tabriz (Iran)(Pourjafar et al., 2014), $0.18-0.35(\mathrm{dw})$ in tuna fish muscles (Ahmed et al., 2015), 0.58-1.04 in canned fish from Tehran (Iran) (Fathabad et al., 2015), 0.14-0.37 in Iran (Hosseini et al., 2015) and 0.14-0.37 (0.22) in Iran (Sobhanardakani et al., 2018).

The estimated weekly intake $(\mu \mathrm{g} / \mathrm{kg} \mathrm{BW} /$ week) values for $\mathrm{Ni}$ in this study in the samples examined canned tuna from the five brands were as following $7.126,6.818,6.734,6.545$ and 6.853 respectively (table 4). These estimated values were lower than that permitted by WHO (1992) as the maximum acceptable weekly intake is $700-2100 \mu \mathrm{g} / \mathrm{kg}$ bw. The EDI $(\mu \mathrm{g} / \mathrm{kg} /$ day $)$ is lower than that set by WHO (1992) as MPL is 100-300. WHO recommends $100-300 \mu \mathrm{g} \mathrm{Ni}$ for daily intake (WHO, 1994). The upper tolerable intake level of nickel for children (1-3 years old) and males/females (19-70 years old) is 7 and 40 $\mathrm{mg} /$ day, respectively (Institute of Medicine, 2003). It is reported that maximum nickel level in some food samples is $0.2 \mathrm{mg} / \mathrm{kg}$ (Muchuweti et al., 2006; Tuzen, 2009).

Nickel content in the examined samples in this study is higher than that recorded by Hussein and Khaled (2014) as they found Ni content $0.37 \mathrm{mg} /$ $\mathrm{kg}$ in muscle in tuna fish in the three locations in Egypt.

Nickel is essential for reproduction and normal growth in animals and human beings. Ni showed carcinogenic effect when taken in high amount (Malik et al., 2010). Major sources of $\mathrm{Ni}$ in humans are processed food and uptake from natural resources (Cronin et al., 1998). In the environment, $\mathrm{Ni}$ is normally found at very low levels. In high concentrations it can result in pulmonary adverse effects, such as lung inflammation, fibrosis, emphysema, and tumors (Forti et al., 2011). Nickel can accumulate in tuna tissue. $\mathrm{Ni}$ can cause respiratory difficulties, nervous and digestive disorders, psychological problems, and also it is carcinogenic (Ikem and Egiebor, 2005; Ashraf et al., 2006). Ni acute toxicity arises from competitive interaction with five major essential elements such as copper, calcium, iron, cobalt and zinc (Moore and Ramamoorthy, 1984).

[6] Cobalt: Co content (ppm) in examined canned tuna samples in the five brands were $1.322 \pm 0.149$ (0.765-1.656), $\quad 1.757 \pm 0.082 \quad(1.515-1.957)$, $2.089 \pm 0.165(1.607-2.525), 2.511 \pm 0.123 \quad(2.160$ $2.785), \quad 2.719 \pm 0.110 \quad 2.381-3.072)$ respectively, while in total samples was $2.080 \pm 0.16(0.765$ 3.072) (table1, figures 1-5).

The Co values ( $\mathrm{mg} / \mathrm{kg}$ wet weight) recorded in this study in examined canned were higher than that reported by other literatures as documented in Masan Bay with an average of $0.01 \mu \mathrm{g} / \mathrm{g}$ (Kwon and Lee 2001), Topcuoglu et al. (2002) reported concentrations of cobalt with a range $<0.05-0.40$ $\mu \mathrm{g} / \mathrm{g}$ in the black Sea coast, Suresh et al. (2007) recorded Co with a range of $0.05-0.28 \mu \mathrm{g} / \mathrm{g}$ in Parangipettai coast of India, Ozparlak et al. (2012) found that Co content in muscles of fish from Beysehir Lake, Turkey was $2.68 \mathrm{mg} / \mathrm{kg}$, Dhaneesh et al. (2014) found that Co content in different types of canned tuna in India was $0.173 \pm 0.011$ $\mathrm{ug} / \mathrm{g}$, while in muscles of fresh fish was $0.009 \pm$ $0.006 \mathrm{ug} / \mathrm{g}$, Javed and Usmani (2016) found that Co content in fish in India was $9.06 \mathrm{mg} / \mathrm{kg}$, Zaqoot et al. (2017) found that Co content $(\mu \mathrm{g} / \mathrm{g}$ wet 
weight) in fish collected from Gaza fishing harbor in the Mediterranean sea along Gaza coast, Palestine was nd-2.93 (average 0.68) and in muscles of fish from selected rivers in district Charsadda, Pakistan was 0.23-0.25 (mg/kg ww) (Idrees et al., 2017).

The estimated weekly intake $(\mu \mathrm{g} / \mathrm{kg} \mathrm{BW} /$ week) values for Co in this study in the samples examined canned tuna from the five brands were as following $4.627,6.153,7.313,8.792$ and 9.520 respectively (table 4). These estimated values were lower than that permitted by NRC (1989) as the maximum acceptable weekly intake is $420 \mu \mathrm{g} / \mathrm{kg}$ bw.

Cobalt is an essential important element for many enzymes and vitamins such as vitamin $\mathrm{B}_{12}$. When the consumer exposed to high levels of Co from cardiac, pulmonary and skin effects (ATSDR, 2004).

[6] Chromium: Chromium concentrations (ppm) in all examined canned tuna samples in the five brands were $0.246 \pm 0.100 \quad(0.000-0.573)$, $0.039 \pm 0.03(0.000-0.156), \mathrm{ND}, \mathrm{ND}, 0.030 \pm 0.023$ (0.000-0.120) respectively, while in total samples was $0.063 \pm 0.027$ (ND-0.573) (table1, figures 1-5). All these concentrations of $\mathrm{Cr}$ were lower than the maximum acceptable limits (ppm) recommended by different authorities and agencies such as WHO (1996) which sets that the total concentrations of $\mathrm{Cr}$ have been found in fish to range from 0.01-1.3 $\mu \mathrm{g} / \mathrm{g}$; USEPA (2002) as 8, IAEA-407 (Wyse et al., 2003) as 0.73 and WHO (2006) as 0.2 in fish.

The $\mathrm{Cr}$ values ( $\mathrm{mg} / \mathrm{kg}$ wet weight) recorded in this study in examined canned were higher than that reported by other literatures as in the USA was $0.0-0.30 \mu \mathrm{g} / \mathrm{g}$ (Ikem and Egiebor, 2005). $\mathrm{Cr}$ content was $0.38(0.10-0.57)$ in canned tuna in Saudi Arabia (Ashraf, 2006), 0.97-1.70 in canned fish in Turkey (Tuzen and Soylak, 2007), 9.32210.022 (average 9.689) in canned tuna in Egypt (Ahdy et al., 2009), 0.02 in canned tuna in Nigeria (Iwegbue et al., 2009), 0.09-1.32 in canned fish (Islam et al., 2010), Islam et al. (2010) reported that $\mathrm{Cr}(\mu \mathrm{g} / \mathrm{g}, \mathrm{DW})$ in canned longtail tuna which was imported from the USA, canned bluefin tuna which was imported from the Thailand and canned bluefin tuna (produced in Korea) were 0.58, 0.32 and 0.25; El-Sadaawy et al. (2011) when examined canned tuna fish market in Egypt found that $\mathrm{Cr}$ was 0.186-0.322 (average 0.251) $\mu \mathrm{g} / \mathrm{g}$ wet weight, while was $0.65-3.24(2.66 \mu \mathrm{g} / \mathrm{g}$ wet weight $)$ in canned tuna fish in Iran (Sobhanardakani et al., 2018). 0.245 in canned tuna in India (Dhaneesh et al., 2014), 0.90-1.87 $\mu \mathrm{g} / \mathrm{g}$ in canned fish from Tehran (Iran) (Fathabad et al., 2015), 1.65-3.24 $\mu \mathrm{g} / \mathrm{g}$ in canned fish in Iran (Hosseini et al., 2015),
$0.0-0.30 \mu \mathrm{g} / \mathrm{g}$ in canned fish (Ulouzlu et al., 2007, Guerin et al., 2011, Morgano et al., 2011).

The estimated weekly intake $(\mu \mathrm{g} / \mathrm{kg} \mathrm{BW} /$ week) values for $\mathrm{Cr}$ in this study in the samples examined canned tuna from the five brands were as following $0.861,0.140, \mathrm{NE}, \mathrm{NE}$ and 0.105 respectively (table 4). These estimated values were lower than that permitted by NRC (1989) as the maximum acceptable weekly intake is $420 \mu \mathrm{g} / \mathrm{kg}$ bw.

Sobhanardakani et al. (2018) reported that the average HRI values for adults and children were $1.23 \mathrm{E}-04$ and $5.73 \mathrm{E}-04$ respectively, and therefore, the non-carcinogenic risks for children are greater than adults. In this regard, Hussein and Khaled (2014) reported that the from the human health point of view, $\mathrm{Cr}, \mathrm{Cu}$, and $\mathrm{Mn}$, THQ values were less than 1 and show a situation of no risk for the consumer of the investigated tuna species collected from the Alexandria, Egypt. Ordiano-Flores et al. (2011) reported that the estimated THQ values of $\mathrm{Hg}$ were $<1$ in each population group (children and adults) due to consumption of yellowfin tuna collected from the Eastern Pacific Ocean.

Chromium (III) is an essential nutrient that helps the body use sugar, protein, and fat but $\mathrm{Cr}$ (VI) is carcinogenic (Institute of Medicine, 2003, Ikem and Egiebor, 2005; Tuzen and Soylak, 2006). Excessive amount of Cr (III) may cause adverse health effects (ATDSR, 2004). Chronic exposure to $\mathrm{Cr}$ causes damage to the liver, kidney, circulatory and nerve disorders, as well as skin irritation (Kabata-Pendias, 2010). The US National Research Council recommended daily amount of $\mathrm{Cr}$ as 60 $\mu \mathrm{g} /$ day for a $70 \mathrm{~kg}$ person (NRC, 1989).

Fish can be contaminated by toxic metals during fish growth, transportation, and storage (Ikem and Egiebor, 2005; Fong et al., 2006). Normally, some factors can affect in the accumulation of pollutants like metals in tissues of fish such as concentration of pollutant in water, chemistry of water in it fish live (such as salinity, $\mathrm{pH}$, hardness, and total dissolved solids), feeding habit of fish, duration of exposure of fish to these pollutants as well as contamination of fish during processing, handling, canning and quality of coating of cans and storage place of fish and cans (Tahán et al., 1995; Hosseini et al., 2013). Fish can accumulate large amounts of heavy metals in gills, liver and muscular tissues (Sobhanardakani et al., 2012) which results in health troubles to fish and consumer (Burger and Gochfeld, 2005).

In this study, the Target Health Quotient (THQ) in the total examined tuna samples was 0.219-0.323 (0.254) for $\mathrm{Pb}, 0.308-0.351$ (0.327) for $\mathrm{Cd}$, $0.00176-0.00185(0.00181)$ for $\mathrm{Al}, 2.913-11.380$ 
(7.757) for $\mathrm{Hg}, 0.047-0.051$ (0.049) for $\mathrm{Ni}, 0.033-$ $0.049(0.052)$ for $\mathrm{Co}$ and $0.00001-0.000082$ $(0.000035)$ for $\mathrm{Cr}$.

The investigated canned tuna showed that the Hazard Health Index (HI) for brand 1 was 11.709, for brand 2 was 9.268 , for brand 3 was 12.015 , for brand 4 was 5.604 , for brand 5 was 3.601 , all of these are exceeding 1 . HI exceeding 1 indicates that the metals are toxic and present a hazard to human health (Li et al., 2013).

The difference in concentration of estimated heavy metals in examined tuna may return to the difference sites of rearing, season of catching, sex of fish, age of fish as well as to the length and weight of fish used in preparing of these canned tuna (Kagi and Schaffer, 1998; Agusa et al., 2005 and De Marco et al., 2006).

From these reported results in this study, consumption of these canned tuna represent adverse health problems for the consumers especially for children and elders who are immunological exhausted. Target hazard quotient (THQ) and hazard health index (HI) proposed by USEPA (2015) are parameters for risk assessment which compare the ingestion amount of a pollutant with a standard reference dose and have been widely used in the risk assessment of metals in contaminated foods. The HI value has been recognized as one of the reasonable parameters for the risk assessment of metals associated with the consumption of contaminated fish (Li et al., 2013). A HI below 1 means the exposed population is unlikely to experience obvious adverse effects; whereas a HI above 1 means that there is a chance of harmful effects, with an increasing probability as the value increases (Saha and Zaman, 2012). Storelli (2008) found that THQs for $\mathrm{Hg}, \mathrm{Cd}$, and $\mathrm{Pb}$ in fish from the Adriatic Sea as of $\mathrm{Pb}(0.002-$ 0.18), $\mathrm{Cd}$ (0.01-0.04) and and $\mathrm{Hg}$ (0.08-1.87). Copat et al. (2013) estimated the THQ of metals consumed in fish and shellfish from the eastern Mediterranean Sea, and reported that the THQ values for $\mathrm{Cd}, \mathrm{Cr}$ and $\mathrm{Ni}$ were all below 1 . Values for $\mathrm{THQ}<1$ were also reported for $\mathrm{Cu}, \mathrm{Cd}, \mathrm{Pb}, \mathrm{Hg}$ and $\mathrm{Cr}$ in fish from the Eastern Aegean Sea (Yabanli and Alparslan, 2015).

\section{CONCLUSION}

Potential health risk assessments based on PTWI values, EDI, and THQ indicated that the intakes of metals by consuming these fish species do not result in an appreciable hazard risk for the human body. The HI calculated was higher than 1 for all the species. However, the results indicate that the high concentrations of $\mathrm{Pb}, \mathrm{Cd}, \mathrm{Al}$ and $\mathrm{Hg}$ in fish are alarming and do present an appreciable hazard risk to human health. Regular monitoring for the heavy metals especially $\mathrm{Hg}$ contamination in fish and fishery products is important to protect susceptible vulnerable population such as children, pregnant females and elders.

\section{REFERENCES}

Abd Elgwad, HG. (2003): Some harmful agents in canned fish. Ph.D. Thesis, Fac. Vet. Med., Zagazig Univ., Egypt.

Abida, B.; Harikrishna, S.; Irfanulla, K.; Ramaiah, M.; Veena, K. and Vinutha, K. (2008): Analysis of flouride level in Water and Fish Species of Sankey, Bellandur and Madi- vala Lakes of Bangalore. Rasayan.Jounal of Chemistry, 3, 596- 601.

Abolghait, SK. and Garbaj, AM. (2015): Determination of cadmium, lead and mercury residual levels in meat of canned light tuna (Katsuwonus pelamis and Thunnus albacares) and fresh little tunny (Euthynnus alletteratus) in Libya. Open Veterinary Journal, 5(2): 130137.

Adil, C.; Mustaphab, H.; Abdeljalilb, B. and Taoufiq, $B$. (2015): Heavy metals content of canned tuna fish: estimated weekly intake. Mor. J. Chem., 3 (1): 152-156.

Agusa, T.; Kunito, T.; Yasunga, G.; Iwata, H.; Subramanian, A.; Ismail, A. and Tanabe, S. (2005): Concentration of trace elements in marine fish and its risk assessment in Malaysia. Marine Pollution Bulletin, 51: 896911.

Ahdy, HHH.; Mohamed, LA.; Khaled, A. and ElSikaily, A. (2009): Canned fish between benefits and risks on the Egyptian market. Egyptian J of Aquatic Research, 35(4): 511520.

Ahmad, AK. and Othman, ShM. (2010): Heavy metal concentrations in sediments and fishes from Lake Chini, Pahang. Malay. J. Biol. Sci., 10: 93-100.

Ahmed, Q.; Bat, L. and Yousuf, F. (2015): Accumulation of heavy metals in tissues of long tail tuna from Karachi fish Harbour, Pakistan. Aquatic Sci and Technology, 3(1): 103-115.

Akan, EA.; Abbagambo, MT.; Chellube, ZM. and Abdulrahman, FI. (2012): Assessment of pollutants in water and sediment samples in lake Chad, Baga, North Eastern Nigeria. J of Environmental Protection, 3: 1428-1441.

Ashraf, W. (2006): Levels of selected heavy metals in tuna fish. The Arabian $\mathbf{J}$ for Science and Engineering, 31 (1A): 89-92.

Ashraf, W.; Seddigi, Z.; Abulkibash, A. and Khalid, M. (2006): Levels of selected metals in canned fish consumed in kingdom of Saudi Arabia. Environ Monit Assess., 117: 271-279. 
ATSDR (Agency for Toxic Substances and Disease Registry) (2004): Division of Toxicology, Clifton Road, NE, Atlanta, GA, 223p.

ATSDR (2012): Toxicological Profile for Cadmium. Atlanta: U.S. Department of Health and Humans Services, Public Health Service, Centres for Diseases Control.

Babatunde, AM.; Abdul, WO. and Akinyemi, AA. (2012): Bioaccumulation of heavy metals in fish (Hydrocynus forskahlii, Hyperopisus bebe occidentalis and Clarias gariepinus) organs in downstream Ogun coastal water, Nigeria. J of Agricultural Sci., 4(11): 119-133.

Bahnasawy, M.; Khidr, AA. and Dheina, N. (2011): Assessment of heavy metal concentrations in water, plankton, and fish of Lake Manzala, Egypt. Turkish J of Zoology, 35(2): 271-280.

Boadi, NO.; Twumasi, SK.; Badu, M. and Osei, I. (2011): Heavy metal contamination in canned fish marketed in Ghana. Am. J. Sci. Ind. Res., 2(6): 877-882.

Bratt, L. (2010): Fish Canning Handbook. WileyBlackwell.

Burger, J. and Gochfeld, M. (2004): Mercury in canned tuna: white versus light and temporal variation. Environmental Research, 96, 239249

Burger, J. and Gochfeld, M. (2005): Heavy metals in commercial fish in New Jersey. Environmental Research, 99(3): 403-412.

Burger, J.; Gaines, KF.; Boring, CS.; Stephens, WL.; Snodgrass, J.; Dixon, C.; McMahon, M.; Shukla, S.; Shukla, T. and Gochfeld, M. (2002): Metal levels in fish from the Savannah River potential hazards to fish and other receptors. Environmental Res., 89: 85-97.

CAC (2012): Codex Alimentarius Commission. Joint FAO/WHO food standards programme Codex Committee on contaminants in foods sixth session.

Camargo, MMP.; Fernandes, MN. and Martinez, CBR. (2009): How aluminium exposure promotes osmoregulatory disturbances in the neotropical freshwater fish Prochilus lineatus. Aquat. Toxicol., 94: 40-46.

Casarini, DCP.; Dias, CL. and Alonso, CD. (2001): Relatório de estabelecimento de valores orientadores para solos e águas subterrâneas no Estado de São Paulo. Série Relatórios. CETESB, São Paulo

Celik, U. and Oehlenschlager, J. (2007): High contents of cadmium, lead, zinc and copper in popular fishery products sold in Turkish supermarkets. Food Control, 18(3): 258-261.

Chen, CY.; Lai, CC.; Chen, KS.; Hsu, CC.; Hung, CC. and Chen, MH. (2014): Total and organic mercury concentrations in the muscles of Pacific albacore (Thunnus alalunga) and bigeye tuna (Thunnus obesus). Mar Pollut Bull. Elsevier Ltd; 85(2): 606-612.
Ciesielski, T.; Pastukhov, MV.; Szefer, P. and Jensen, BM. (2010): Bioaccumulation of Mercury in the pelagic food chain of Lake Baikal. Chemosphere., 78: 1378-1384.

CIFA (Committee for Inland Fisheries of Africa) (1992): Report of the Third Session of the Working Party on Pollution and Fisheries, FAO Fisheries Report No 471, Food and Agriculture Organisation of the United Nations, Rome, 43p.

Ciobanu, C.; Slencu, BG. and Cuciureanu, R. (2012): Estimation of dietary intake of cadmium and lead through food consumption. Rev. Med. Chir. Soc. Med. Nat. Iasi., 116(2): 617-623.

Commission of the European Communities (2001): Commission Regulation (EC), No. 221/2002 of 6 February 2002 amending regulation (EC) No. 466/2002 setting maximum levels for certain contaminations in foodstuffs. Official $\mathbf{J}$ Eur Uni. Brussels, Belgium.

Copat, C.; Bella, F.; Castaing, M.; Fallico, R.; Sciacca, S. and Ferrante, M. (2013): Heavy metals concentrations in fish from Sicily (Mediterranean Sea) and evaluation of possible health risks to consumers. Bulletin of Environ. Contamination and Toxicology, 88(1): 78-83.

Correia, TG.; Narcizo, AM.; Bianchini, A. and Moreira, RG. (2010): Aluminum as an endocrine disruptor in female Nile tilapia (Oreochromis niloticus). Comp. Biochem.Physiol., Part C 151: 461-466.

Cronin, M.; Davies, IM.; Newton, A.; Pirie, JM.; Topping, G. and Swan, S. (1998): Trace metal concentrations in deep sea fish from the North Atlantic. Marine Mar Environ Res., 45(3): 225-238.

Denton, GRW. and Burdon-Jones, C. (1986): Trace metals in fish from the Great Barrier Reef. Mar Pollut Bull., 17:201-209.

De Marco, SG.; Botte, SE. and Marrcovecchio, JE. (2006): Mercury distribution in biotic and biological compartments within several estuarine systems from Argentina, 1980-2005 periods. Chemosphere, 65: 213-223.

Dhaneesh, KV.; Noushad, KM.; Biju Kumar, A.; Nobi, EP. and Nabeel, AM. (2014): Heavy metals content in Yellowfin tuna Thunnus Albacares (Bonnaterre) of Lakshadweep Sea. Carpathian Journal of Earth and Environmental Sciences, 9(4):55-59.

Demirel, S.; Tuzen, M.; Saracoglu, S. and Soylak, M. (2008): Evaluation of various digestion procedures for trace element contents of some food materials. $\mathrm{J}$ of hazardous materials, 152(3):1020-6.

Du Preez, HH. and Steyn, GJ. (1992): A preliminary investigation of the concentration of selected metals in the tissues and organs of the tigerfish (Hydrocynus vittatus) from the Olifants River, 
Kruger National Park, South Africa. Water SA18 (2): 131-136.

EC (2001): Commission of the European Communities. (2001): Commission Regulation (EC) No. 221/2002 of 6 February 2002 amending regulation (EC) NO. 466/2002 setting maximum levels for certain contaminants in foodstuffs. Official J. European Commucities, Brussels, 6 February 2002.

EC (European Commission) (2006): Commission Regulation No. 1881/2006 of 19 December 2006 setting maximum levels for certain contaminants in foodstuffs. Official Journal of European Union, 20.12.2006

EFSA (European Food Safety Authority) (2009): Scientific panel on contaminants in the food chain. $\mathrm{Cd}$ in food 30/01/2009. Belgium: EFSA; 2009/03/20. The EFSA Journal 980 (2009) 1-139.

EOS (Egyptian Organization for Standardization and Quality control) (2005): Maximum residues limits for heavy metals in food. "Ministry of Industry" No. 2360/2005. Cairo, Egypt.

Eisler, R. (2010): Fishes. In Compendium of Trace Metals and Marine Biota, Ed., Eisler, R. Elsevier, Amsterdam, pp: 39-220.

El-Sadaawy, MM.; Morsy, FA.; Ahdy, HHH.; Abdel Fattah, LM.; El-Sikaily, A. and Khaled, A. (2011): Public health implication of consuming canned fish. Egyptian J of Aquatic Research, 37(4): 313-323.

Emami Khansari, F.; Ghazi-Khansari, M. and Abdollahi, M. (2005): Heavy metals content of canned tuna fish. Food Chem. 93: 293-296.

Engström, A.; Michaëlsson, K.; Vahter, M.; Julin, B.; Wolk, A. and Akesson, A. (2012): Associations between dietary cadmium exposure and bone mineral density and risk of osteoporosis and fractures among women. Bone, 50:1372-1378.

EOSQC "Egyptian Organization for Standardization and Quality Control" (1993): Maximum residue limits for heavy metals in food, Ministry of Industry No. 2360: 5, Cairo, Egypt.

Erdogrul, O. and Erbilir, F. (2007): Heavy metals and trace elements in various fish samples from Sir Dam Lake, Kahramanmaras, Turkey. Environ Monitoring \& Assessment, 130: 373379.

$E U$ (2005): Commission regulation as regards heavy metals. Amending Regulation, 466/2001, No. $78 / 2005$.

FAO (1983): Compilation of legal limits for hazardous substances in fish and fishery products. In: FAO Fishery Circular, Inland Water Resources and Aquaculture Service, No.464. Rome, Italy. p.5-100.

FAO/WHO (1989): Joint F, Additives WECoF, Organization WH. Evaluation of certain food additives and contaminants: thirty-third report of the Joint.

FAO/WHO (1992): Codex Alimentarius Commission, standard program codex committee on food additives and contaminants $24^{\text {th }}$ Session, Hague, 23-28 March.

FAO/WHO (2003): Evaluation of certain food additives and contaminants. Geneva: 61 st report of the joint $\mathrm{FAO} / \mathrm{WHO}$ expert committee on Food additives.

FAO/WHO (2011): Evaluations of the Joint FAO/WHO Expert committee on food additives (JECFA). http://apps.who.int/ipsc/ database/evaluations/search.as

FAO/WHO Expert Committe on Food Additives. Cd [Internet]. (2013): [cited 2014 Nov 20].

Farkas, A.; Salánki, J. and Specziár, A. (2003): Ageand size-specific patterns of heavy metals in the organs of freshwater fish Abramis brama L. populating a low-contaminated site. Water Res., 37(5): 959-64

Fathabad, AE.; Shariatifar, N.; Ehsani, A. and Sayadi, M. (2015): Evaluation of toxic metals in canned fish market in Tehran. Intern. $J$ of Pharma Sci. and Res. (IJPSR), 6(5): 818-822.

Fong, SS.; KanaKaraju, DAP. and Ling, SC. (2006): Evaluation of the acid Digestion method with Different Solvent Combination for the Determination of Iron, Zinc and Lead in canned sardines. Malaysian Journal of Chemistry, 8(1): 10-15.

Forti, E.; Salovaara, S.; Cetin, Y.; Bulgheroni, A.; Tessadri, R. and Jennings P. (2011): In vitro evaluation of the toxicity induced by nickel soluble and particulate forms in human airway epithelial cells. Toxicol Vit., 25(2):454-61.

Ganjavi, M.; Ezzatpanah, H.; Givianrad, M. and Shams, A. (2010): Effect of canned tuna fish processing steps on lead and cadmium contents of Iranian tuna fish. Food chemistry, 118 (3): 525-528.

Guérin, T.; Chekri, R.; Vastel, C.; Sirot, V.; Volatier J-L. and Leblanc J-C. (2011): Determination of 20 trace elements in fish and other seafood from the French market. Food Chemistry. 127(3): 934-42.

Havelková, M.; Dušek, L.; Némethová, D.; Poleszczuk, G. and Svobodová, Z. (2008): Comparison of mercury distribution between liver and muscle - A biomonitoring of fish from lightly and heavily contaminated localities. Sensors. 8(7): 4095-109.

Honggang, Z.; Baoshan, C.; Rang, X. and Hui, Z. (2010): Heavy metals in water, soils and plants in Riparian wetlands in the Pearl River Estuary, South China. Procedia Environ. Sci., 2: 1344-1354.

Hosseini, SV.; Aflaki, F.; Sobhanardakani, S.; Tayebi, L.; Babakhani Lashkan, A. and Regenstein, JM. (2013): Analysis of mercury, selenium and tin concentrations in canned fish marketed 
in Iran. Environmental Monitoring and Assessment, 185(8): 6407-6412

Hosseini, SV.; Aflaki, F.; Sobhanardakani, S. and Langaroudi, SB. (2015): Selected Metals in Canned Fish Consumed in Iran. Iranian Journal of Toxicology, 8 (27): 1182-1187.

Hussein, A. and Khaled, A. (2014): Determination of metals in tuna species and bivalves from Alexandria, Egypt. Egyptian Journal of Aquatic Research, 40: 9-17.

IARC (1993): Beryllium, cadmium, mercury and exposure in the glass manufacturing industry. In: Cadmium and Cadmium Compounds. Vol. 58. WHO Press, Lyon, pp119-237.

IARC (International Agency for Research in Cancer) (2014): Monographs on the evaluation on carcinogenics risks to humans [Internet]. 2014 [cited 2014 Sep 11]

Idrees, M.; Jan, FA.; Ara, A.; Begum, ZM.; Mahmood, M. and Gulab, H. (2017): Analysis and human health risk from selected heavy metals in water, sediments and fresh water fish (Labeo Rohita, Cyprinus Carpio, Glyptothorax Punjabensis) collected from three rivers in district Charsadda, Khyber-Pakhunkhwa, Pakistan. Carpathian $\mathbf{J}$ of Earth and Environ. Sci., 12(2): 641-648.

Ikem, A. and Egiebor, NO. (2005): Assessment of trace elements in canned fishes (Mackerel, Tuna, Salmon, Sardines and Herrings) marketed in Georgia and Alabama (United state of America). Journal of Food Composition and Analysis, 18: 771-787.

Institute of Medicine (2003): Dietary Reference Intakes: Applications in Dietary Planning. Subcommittee on Interpretation and Uses of Dietary Reference Intakes and the Standing Committee on the Scientific Evaluation of Dietary Reference Intakes. Institute of Medicine of the National Academies, The National Academies Press, Washington, DC, p. 248.

Islam, MM.; Bang, S.; Kim, K-W.; Ahmed, MK. and Jannat, M. (2010): Heavy Metals in Frozen and Canned Marine Fish of Korea. J. Sci. Res. 2 (3): 549-557.

Ismail, HM. (2005): The role of omega-3 fatty acids in cardiac protection: An overview. Frontiers of Bioscience, 10: 1079-1088.

Iwegbue, C.; Nwajei, G.; Arimoro, F. and Osa, E. (2009): Characteristic levels of heavy metals in canned sardines consumed in Nigeria. Environmentalist, 29:431-435

Jan, FA.; Ishaq, M.; Khan, S.; Ihsanullah, I.; Ahmad, I. and Shakirullah, M. (2010): A comparative study of human health risks via consumption of food crops grown on wastewater irrigated soil (Peshawar) and relatively clean water irrigated soil (lower Dir). J Hazardous Materials, 179: 612-621.
Jarup, L. (2003): Hazards of heavy metal contamination, Brit. Med. Bull., 68: 167-182

Javed, M. and Usmani, N. (2016): Accumulation of heavy metals and human health risk assessment via the consumption of freshwater fih Mastacembelus armatus inhabiting, thermal power plant effluent loaded canal. Javed and Usmani Springer Plus, 5: 776.

Jomova, K. and Valko, M. (2011): Advances in metalinduced oxidative stress and human disease. Toxicology 283: 65-87.

Kabata-Pendias, A. (2010): Trace Elements in Soils and Plants, Fourth Edition. Florida, USA, CRC Press., 548 pp.

Kagi, JH. and Schaffer, A. (1998): Biochemistry of metallothionein. Biochemistry, 27: 8509-8515.

Kakkar, P. and Jaffery, FN. (2005): Biological markers for metal toxicity. Environ Toxicol Pharmacol 19: 335-349, 2005.

Kazi, TG.; Jalbani, N.; Baig, JA.; Kandhro, GA.; Afridi, HI.; Arain, BM.; Jamali, M.K. and Shah, AQ. (2009): Assessment of toxic metals in raw and processed milk samples using electrothermal atomic absorption spectrophotometer. Food Chem. Toxicol., 47: 2163-2169.

Kehrig, H.; Malm, O. and Moreira, I. (1998): Mercury in a widely consumed fish Micropogonias furnieri (Demarest, 1823) from four main Brazilian estuaries. Sci Total Environ. 213:263-71.

Khansari, FE.; Ghazi-Khansari, M. and Abdollahi, M. (2005): Heavy metals content of canned tuna fish. Food Chem., 93 (2): 293-296.

Kojadinovic, J.; Potier, M.; Le Corre, M.; Cosson, RP. and Bustamante, P. (2007): Bioaccumulation of trace elements in pelagic fish from the Western Indian Ocean Environmental Pollution, 146(2): 548-566.

Kumar, M.; Lakshya, T. and Viraj, R. (2013): Features of weighty metals in canned tuna fish. Advances in Aquaculture and Fisheries Management Vol. 1 (6), pp. 058-059

Kwon, YT. and Lee, CW. (2001): Ecological risk assessment of sediment in wastewater discharging area by means of metal speciation. Microchemical Journal, 70 (3): 255-264.

Li, J.; Huang, Z.; Hu, Y. and Yang, H. (2013): Potential risk assessment of heavy metals by consuming shellfish collected from Xiamen, China. Environ Sci and Pollution Res., 20(5): 2937-47.

Mahalakshmi, M.; Balakrishnan, S.; Indira, K. and Srinivasan, M. (2012): Characteristic levels of heavy metals in canned tuna fish. $\mathbf{J}$ of Toxicology and Environ Health Sci, 4(2): 4345.

Malakootian, M.; Tahergorabi, M.; Daneshpajooh, M. and Amirtaheri, K. (2011): Determination of $\mathrm{Pb}, \mathrm{Cd}, \mathrm{Ni}$, and $\mathrm{Zn}$ concentrations in canned 
fish in southern Iran. Sacha J Environ Stud., 1: 94-100.

Malik, N.; Biswas, AK.; Qureshi, TA.; Borana, K. and Virha, R. (2010): Bioaccumulation of heavy metals in fish tissues of a freshwater lake of Bhopal. Environ Monitoring and Assessment, 160: 267-276.

Mendil, D.; Demirci, Z.; Tuzen, M. and Soylak, M. (2010): Seasonal investigation of trace element contents in commercially valuable fish species from the Black sea, Turkey. Food Chem. Toxicol., 48: 865-870.

Moiseenko, TI.; Gashkina, NA.; Sharova, YuN. and Kudriavtseva, LP. (2008): Ecotoxicological assessment of water quality and ecosystem health: A case study of the Volga River. Ecotox. Environ. Saf., 71:837- 850.

Mol, S. (2011): Determination of trace metals in canned anchovies and canned rainbow trouts. Food Chem Toxicol. 49: 348-351.

Moore, JW. and Ramamoorthy, S. (1984): Heavy Metals in Natural Waters: Applied Monitoring and Impact Assessment. Springer-Verlag, New York, USA. 268

Morgano, MA.; Rabonato, LC.; Milani, RF.; Miyagusku, L. and Balian SC. (2011): Assessment of trace elements in fishes of Japanese foods marketed in São Paulo (Brazil). Food Control., 22(5): 778-85.

Morshdy, AMA.; Hafez, AS.; Darwish, WS.; Hussein, MAM. and Tharwat, AE. (2013): Heavy metal residues in canned fishes in Egypt. Japanese $\mathbf{J}$ of Vet. Research, 61: S54-S57.

Muchuweti, M.; Birkett, J.; Chinyanga, E.; Zvauya, R.; Scrimshaw, MD. and Lester, J. (2006): Heavy metal content of vegetables irrigated with mixtures of wastewater and sewage sludge in Zimbabwe: implications for human health. Agriculture, Ecosystems \& Environment, 112(1): 41-8.

Narin, I.; Tuzen, M. and Soylak, M. (2004): Aluminium determination in environmental samples by graphite furnace atomic absorption spectrometry after solid phase extraction on Amberlite XAD-1180/pyrocatechol violet chelating resin. Talanta., 63(2): 411-418.

NRC (National Research Council) (1989): National Research Council recommended dietary allowances. 10th ed. Washington: National Academy Press.

Occupational Safety and Health Administration (2004): Toxic metals, Occupational Safety and Health Administration. US department of labor, 200 constitution avenue, NW, Washington DC, USA

Ordiano-Flores, A.; Galván-Magaña, F. and Rosiles Martínez, R. (2011): Bioaccumulation of mercury in muscle tissue of yellowfin tuna, Thunnus albacares, of the Eastern Pacific Ocean. Biological Trace Element Research, 144(1-3): 606-620.
Ozden, O. (2010): Micro, macro mineral and proximate composition of Atlantic bonito and horse mackerel: a monthly differentiation. Int. J. Food Sci. Technol., 45:578-586.

Özparlak, H.; Arslan, G. and Arslan, E. (2012): Determination of Some Metal Levels in Muscle Tissue of Nine Fish Species from Beyşehir Lake, Turkey. Turkish Journal of Fisheries and Aquatic Sciences, 12: 761-770.

Pappalardo, AM.; Copat, C.; Ferrito, V.; Grasso, A. and Ferrante, M. (2017): Heavy metal content and molecular species identification in canned tuna: Insights into human food safety. Molecular Medicine Reports 15: 3430-3437

Pourjafar, H.; Ghasemnejad, R.; Noori, N. and Mohammadi, Kh. (2014): Heavy metals content of canned tuna fish marketed in Tabriz, Iran. Iranian $\mathbf{J}$ of Vet Medicine (IJVM), 8(1): 9-14.

Rahimi, E. and Behzadnia, A. (2011): Determination of Mercury in Fish (Otollithes ruber) and Canned Tuna Fish in Khuzestan and Shiraz, Iran. World Applied Sci. J, 15(11): 1553-1556.

Ranau, R.; Oehlenschläger, J. and Steinhart, $H$. (2001): Aluminium levels of fish fillets baked and grilled in aluminium foil. Food Chemistry, 73(1): 1-6.

Rauf, A.; Javed, M. and Ubaidullah, M. (2009): Heavy metal levels in three major carps (Catla catla, Labeo rohita and Cirrhina mrigala) from the River Ravi, Pakistan. Pakist. Vet. J., 29(1): 24-26.

Ruelas-Inzunza, J.; Patino-Mejla, C.; Soto-Jimenez, M.; Barba-Quintero, G. and SpanopoulosHernandez, M. (2011): Total' mercury in canned yellowfin tuna Thunnus albacares marketed in northwest Mexico. Food and Chemical Toxicology, 49(12): 3070-3073.

Ruelas-Inzunza, J.; Soto-Jimenez, MF.; RuizFernandez, AC.; Ramos-Osuna, M.; Mones-Saucedo, J. and Paez-Osuna, F. (2014): ${ }^{210} \mathrm{Po}, \mathrm{Cd}$ and $\mathrm{Pb}$ distribution and biomagnification in the yellowfin tuna Thunnus albacares and skipjack tuna Katsuwonus pelamis from the Eastern Pacific. Mar. Pollut. Bull., 87: 98-103.

Saad, MS.; Faten, SH. and Suhair, S Eldin (2014): Lead and mercury as heavy metal residues in imported canned fish products. Benha Veterinary Medical J, 26 (2): 119-125.

Saha, N. and Zaman, MR. (2012): Evaluation of possible health risks of heavy metals by consumption of foodstuffs available in the central market of Rajshahi City, Bangladesh. Environmental Monitoring and Assessment, 185(5): 3867-78.

Satarug, S. (2012): Long-term exposure to cadmium in food and cigarette smoke, liver effects and hepatocellular carcinoma. Curr Drug Metab., 13(3): 257-271. 
Sawada, N.; Iwasaki, M.; Inoue, M.; Takachi, R.; Sasazuki, S.; Yamaji, T.; Shimazu, T.; Endo, Y. and Tsugane, S. (2012): Long-term dietary cadmium intake and cancer incidence. Epidemiology, 23(3): 368-376.

Silva, VS.; Nunes, MA.; Cordeiro, JM.; Calejo, AI.; Santos, S.; Neves, P.; Sykes, A.; Morgado, F.; Dunant, $Y$. and Gonçalves, PP. (2007): Comparative effects of aluminum and ouabain on synaptosomal choline uptake, acetylcholine release and $(\mathrm{Na}+\mathrm{K}+)$ ATPase. Toxicology, 236: 158-177.

Sika, AE.; Ake Assi, Y.; Koffi, KM.; Koffi-Nevry, R. and Biego, H. (2014): Estimation of Some Heavy Metals Intake through Tuna Loins (Thunnus Sp) Produced in Côte D'ivoire. nternational Journal of Applied Science and Technology, 4 (3): 73-80.

Sirot, V; Dumas, C.; Leblanc, JC. and Margaritis, I. (2010): British J of Nutrition, 1-13.

Sobhanardakani, S.; Tayebi, L.; Farmany, A. and Cheraghi, M. (2012): Analysis of trace elements $(\mathrm{Cu}, \mathrm{Cd}$ and $\mathrm{Zn})$ in muscle, gill and liver tissues of some fish species using anodic stripping voltammetry. Environmental Monitoring and Assessment, 184(11), 66076611.

Sobhanardakani, S.; Hosseini, SV. and Tayebi, L. (2018): Heavy Metals Contamination of Canned Fish and Related Health Implications in Iran. Turkish Journal of Fisheries and Aquatic Sciences 18: 951-957

Song, B.; Lei, M.; Chen, T.; Zheng, YM.; Xie, YF.; Li, $X Y$. and Gao, D. (2009): Assessing the health risk of heavy metals in vegetables to the general population in Beijing, China. J Environ Sci (China) 21: 1702-1709

SPSS (2001): Statistical software package for the social sciences. SPSS Inc. United States of America. Cited by http://www.spss.com

Storelli, MM. (2008): Potential human health risks from metals $(\mathrm{Hg}, \mathrm{Cd}$, and $\mathrm{Pb})$ and polychlorinated biphenyls (PCBs) via seafood consumption: estimation of target hazard quotients (THQs) and toxic equivalents (TEQs). Food and Chemical Toxic., 46(8): 2782- 2788

Storelli, MM.; Barone, G.; Cuttone, G.; Giungato, D. and Garofalo, R. (2010): Occurrence of toxic metals $(\mathrm{Hg}, \mathrm{Cd}$ and $\mathrm{Pb})$ in fresh and canned tuna: public health implications. Food Chem. Toxicol. 48, 3167-3170.

Suresh, D.; Manjunatha, $H$. and Srinivasan, $K$. (2007): Effect of heat processing of spices on the concentrations of their bioactive principles: Turmeric (Curcuma longa), red pepper (Capsicum annum) and black pepper (Piper nigrum). Journal of Food Composition and Analysis, 20 (3-4): 346-351.

Tahan, JE.; Sanchez, JM.; Granadillo, VA.; Cubillan, HS. and Romero, RA. (1995): Concentration of total $\mathrm{Al}, \mathrm{Cr}, \mathrm{Cu}, \mathrm{Fe}, \mathrm{Hg}, \mathrm{Na}, \mathrm{Pb}$, and $\mathrm{Zn}$ in commercial canned seafood determined by atomic spectrometric means after mineralization by microwave heating. $\mathrm{J}$ of Agricultural and Food Chemistry, 43(4): 9105.

Topcuoglu, S.; Kirbasoglu, C. and Güngör, N. (2002): Heavy metals in organisms and sediments from Turkish coast of the Black Sea, 1997-1998. Environment Intern, 27(7): 521-526.

Turkmen, A.; Turkmen, M.; Tepe, Y. and Akyurt, I. (2005): Heavy metals in three commercially valuable fish species from Iskenderun Bay, Northern East Mediterranean Sea, Turkey. Food Chemistry, 91(1):167-172.

Tuzen, M. and Soylak, M. (2006): Chromium speciation in environmental samples by solid phase extraction on Chromosorb 108. Journal of Hazard Materials, 129: 266-273.

Tuzen, M. and Soylak, M. (2007): Determination of trace metals in canned fish marketed in Turkey. Food Chemistry, 101(4): 1378-82.

Tuzen, M. (2009): Toxic and essential trace elemental contents in fish species from the Black Sea, Turkey. Food and Chemical Toxicology, 47(8): 1785-90.

Uluozlu, OD.; Tuzen, M.; Mendil, D. and Soylak, M. (2007): Trace metal content in nine species of fish from the Black and Aegean Seas, Turkey. Food Chemistry, 104(2): 835-40.

USEPA (United States Environmental Protection Agency) (1991): Human health evaluation manual, supplemental guidance: Standard default exposure factors. OSWER Directive 9285 6-03 Washington, DC.

USEPA (2002): United States Environment Protection Agency (USEPA), Contaminants in Soil: Collation of Toxicological Data and Intake Values for Humans.

USEPA (United States Environmental Protection Agency) (2015): Regional Screening Level (RSL) Summary Table, November 2015.

Voegborlo, RB.; El-Methnani, AM. and Abedin, MZ. (1999): Mercury, cadmium and lead content of canned tuna fish. Food Chem., 67: 341-345.

Wagner, A. and Boman, J. (2003): Biomonitoring of trace elements in muscle and liver tissue of freshwater fish. Spectrochimica Acta Part B, 58: 2215-2226.

WHO (1989): Evaluation of certain food additives and contaminants. Thirty-third Report of the Joint FAO/WHO Expert Committee on Food Additives. WHO Technical Report series. Geneva: WHO, 776: 26-27.

WHO (1992): Cadmium. Environmental Health Criteria, 134 (Geneva).

WHO (1994): Quality directive of potable water. WHO, Geneva. p.197-8.

WHO (1996): Health criteria other supporting information. In: Guidelines for Drinking Water 
Quality; Vol. 2, 2nd Edn., Geneva,1996.p. 31388.

WHO (2000): Evaluation of certain food additives and contaminants. Report of the Fifty-Third of the Joint FAO/WHO Expert Committee on Food Additives. Technical Report Series No. 896. Geneva.

WHO (World Health Organization), 20-29 June (2006).

WHO (2008): Guidelines for Drinking-Water Quality: Recommendations Incorporating 1 st and $2^{\text {nd }}$ Addenda, vol. 1, World Health Organization, Geneva, Switzerland, $3^{\text {rd }}$ edition, 2008.

WHO (2011): Background document for development of WHO guidelines for drinking-water quality. In: Cadmium in Drinking Water. WHO Press, Geneva, 2011.

Wyse, EJ.; Azemard, S. and Mora, SJ. (2003): Report on the World-wide Intercomparison Exercise for the Determination of Trace Elements and Methylmercury in Fish Homogenate. IAEA407, IAEA/AL/144 (IAEA/MEL/72), IAEA, Monaco.

Yabanli, M. and Alparslan, $Y$. (2015): Potential health hazard assessment in terms of some heavy metals determined in demersal fishes caught in eastern Aegean Sea. Bulletin of Environ Contamination and Toxicology, 95(4), 494-8.

Yilmaz, F. (2009): The comparison of heavy metal concentrations $(\mathrm{Cd}, \mathrm{Cu}, \mathrm{Mn}, \mathrm{Pb}$, and $\mathrm{Zn})$ in tissues of three economically important fish (Anguilla anguilla, Mugil cephalus and Oreochromis niloticus) inhabiting Köycegiz Lake-Mulga (Turkey). Turkish J of Sciences \& Technology, 4(1): 7-15.

Zaqoot, HA.; Aish, AM. and Wafi, HN. (2017): Baseline Concentration of Heavy Metals in Fish Collected from Gaza Fishing Harbor in the Mediterranean Sea along Gaza Coast, Palestine. Turkish Journal of Fisheries and Aquatic Sciences 17: 101 -109 (2017).

Zarei, M.; Mollaie, A.; Eskandari, MH.; Pakfetrat, S. and Shekarforoush, S. (2010): Histamine and Heavy Metals Content of Canned Tuna Fish. Global Veterinaria 5(5):259-263.

Zhou, S.; Belzile, N. and Chen, Y. (1998): Microwave Digestion of Fish Tissues and Determination of $\mathrm{Cu}, \mathrm{Se}$, and $\mathrm{Hg}$ by Atomic Absorption Spectrometry. Int $\mathbf{J}$ of Environ Analytical Chemistry, 72 (3): 205-216.
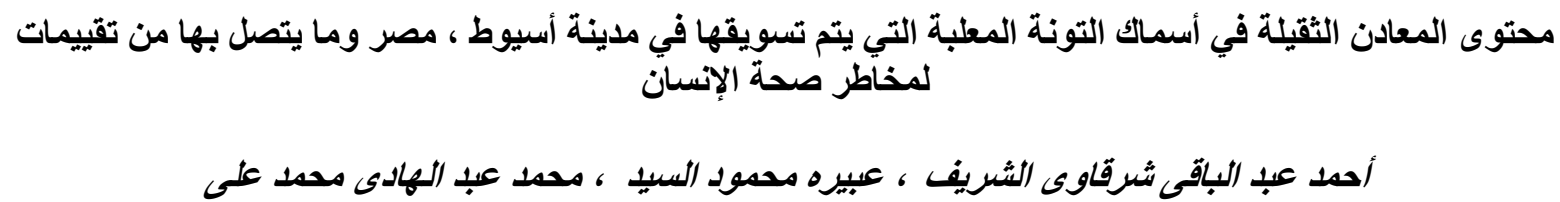

E-mail: ahmedsharkawy61@yahoo.com Assiut University web-site: www.aun.edu.eg

الهدف: بعض المعادن الثقيلة ضارة وخطيرة وتسبب الكثير من المخاطر على الغذاء والصحة العامة. يمكن أن تتر اكم المعادن الثقيلة في الأسماك. قد تتلوث

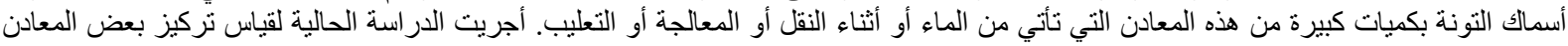

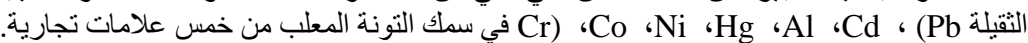

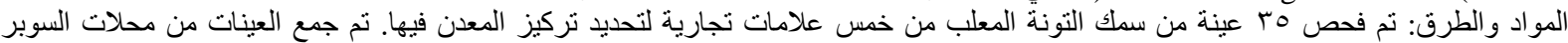

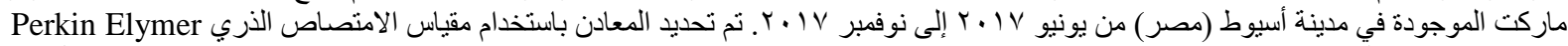

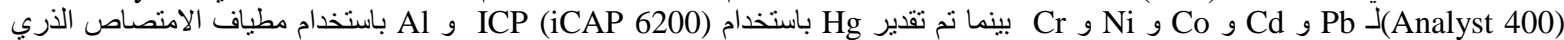

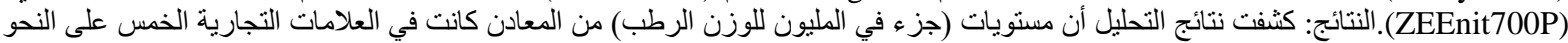
التالي: إل الرصاص: .

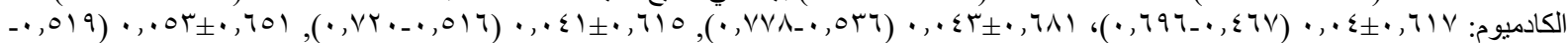
(

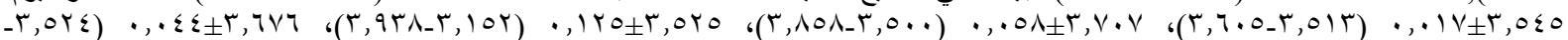
(

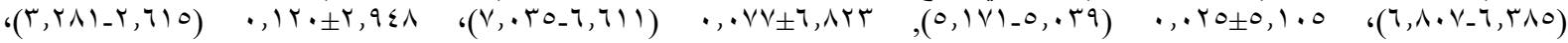

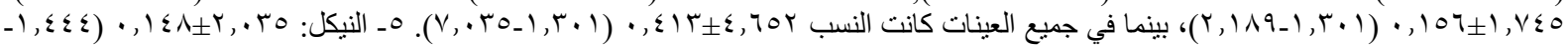

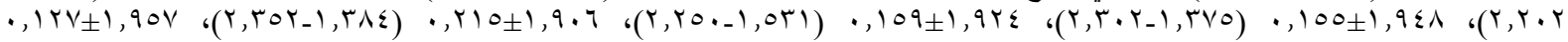

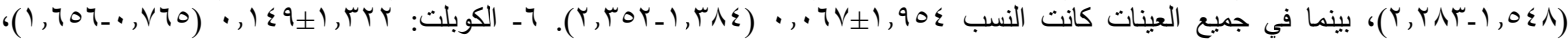

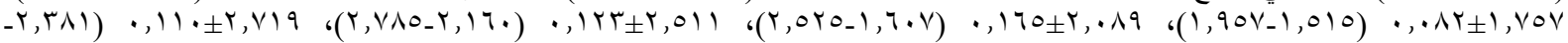

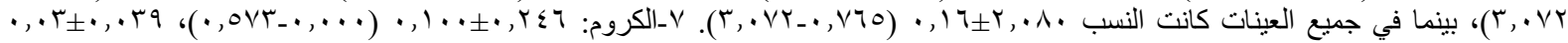

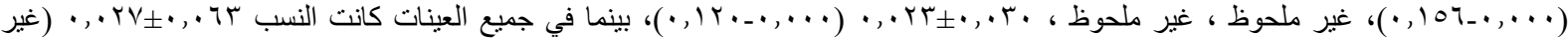

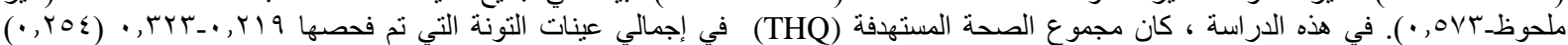

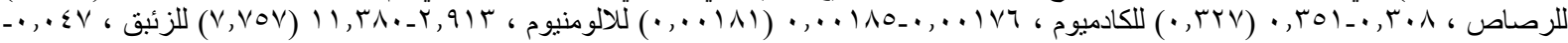

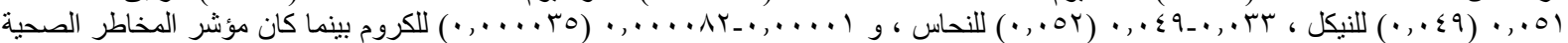

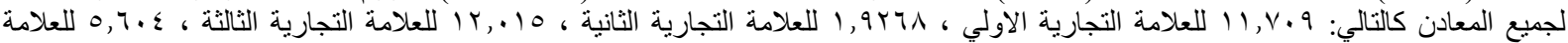

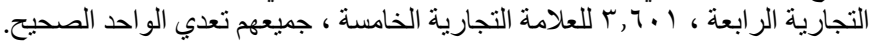

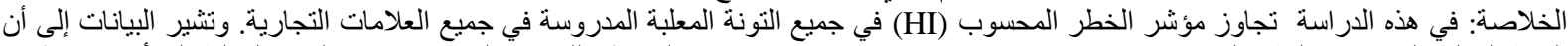

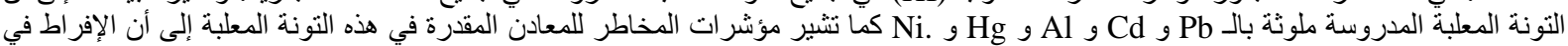

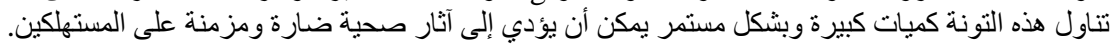


التوصية: أوصت بإجر اء مزيد من الدر اسات الخاصة بتقييمات مر اقبة الجودة للمساعدة في حماية المستهلكين الاصحاء. 